\title{
The Early Acheulean technology of Barranc de la Boella (Catalonia, Spain)
}

\author{
M. Mosquera ${ }^{\text {a, b, * }, ~ A . ~ O l l e ́ ~ a, ~ b ~}{ }^{\text {, P. Saladié }}{ }^{\text {a, b, c }}$, I. Cáceres $^{\text {a, b }}$, R. Huguet ${ }^{\text {a, b, d }}$, A. Rosas ${ }^{\text {e }}$, \\ J. Villalaín ${ }^{\mathrm{f}}$, A. Carrancho ${ }^{\mathrm{g}}$, D. Bourlès ${ }^{\mathrm{h}}$, R. Braucher $^{\mathrm{h}}$, A. Pineda ${ }^{\mathrm{a}, \mathrm{b}}$, J. Vallverdú ${ }^{\mathrm{a}, \mathrm{b}, \mathrm{d}}$ \\ a Àrea de Prehistòria, Universitat Rovira i Virgili (URV), Avinguda de Catalunya, 35, 43002 Tarragona, Spain \\ ${ }^{\mathrm{b}}$ IPHES, Institut Català de Paleoecologia Humana i Evolució Social, Zona educacional 4, Campus Sescelades URV (Edif. W3), 43007 Tarragona, Spain

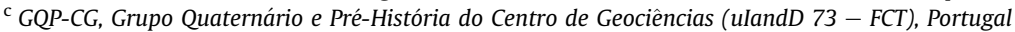 \\ d Unit associated to CSIC, Departamento de Paleobiología, Museo Nacional de Ciencias Naturales (MNCN), Consejo Superior de Investigaciones Científicas \\ (CSIC), Calle José Gutierrez Abascal, 2, 28006 Madrid, Spain \\ e Departamento de Paleobiología, Museo Nacional de Ciencias Naturales (MNCN), Consejo Superior de Investigaciones Científicas (CSIC), Calle José Gutierrez \\ Abascal, 2, 28006 Madrid, Spain \\ ${ }^{\mathrm{f}}$ Laboratorio de Paleomagnetismo (Departamento de Física), Escuela Politécnica Superior - Edificio A1, Universidad de Burgos (UBU), \\ Avenida Cantabria s/n, 09006 Burgos, Spain \\ ${ }^{\mathrm{g}}$ Departamento de Ciencias Históricas y Geografia, Facultad de Humanidades y Educación, C/ Villadiego, s/n, Universidad de Burgos (UBU), \\ 09001 Burgos, Spain \\ ${ }^{\mathrm{h}}$ Aix-Marseille University, CEREGE, CNRS UM34, F-13545 Aix-en-Provence, France
}

\section{A R T I C L E I N F O}

\section{Article history:}

Available online $\mathrm{xxx}$

\section{Keywords:}

European Early Acheulean

Late Early Pleistocene

Barranc de la Boella

Butchering site

Europe

\begin{abstract}
A B S T R A C T
Since 2007, excavations at Barranc de la Boella (Tarragona, Catalonia, Spain) have revealed three localities with rich archaeo-paleontological assemblages: La Mina, El Forn and Pit 1. Palaeontology, palaeomagnetism and cosmogenic analyses have dated these localities to close to 1 Ma. The presence of Mammuthus meridionalis, Hippopotamus antiquus, Stephanorhinus cf. hundsheimensis, Mimomys savini and Victoriamys chalinei stand out in the sample of macro and micro-mammals.

The lithic assemblages from the three sites are made up of percussion cobbles, choppers, choppercores, cores, simple flakes, and some retouched flakes: mainly denticulates and notches. In the case of the El Forn and Pit 1 localities, two large cutting tools have been recovered: a cleaver-like tool and a pick made of hard-wearing schist. The lithic assemblage of Pit 1 , which includes several refitting lithic sets, is closely associated with the remains of a young-adult Mammuthus meridionalis, in a clear butchering site context.

This evidence suggests that Barranc de la Boella is the oldest European Early Acheulean site, and one of the oldest butchering site on the subcontinent during the late Early Pleistocene. The study of the variability among these three localities in similar environmental conditions, together with information from other sites, are discussed in order to gain further knowledge about the appearance of the Acheulean in Europe, and its continuity or discontinuity in relation to pre-existing technologies.
\end{abstract}

(c) 2015 Elsevier Ltd and INQUA. All rights reserved.

\section{Barranc de la Boella}

The Barranc de la Boella site (La Canonja, Spain) is located on the north-eastern Iberian Peninsula, $6 \mathrm{~km}$ away from the present day coastline of the city of Tarragona (Fig. 1). It was a fluvio-deltaic area associated with an incised valley that cut the terrace $T+60$ of the

\footnotetext{
* Corresponding author. Àrea de Prehistòria, Universitat Rovira i Virgili (URV), Avinguda de Catalunya, 35, 43002 Tarragona, Spain.
}

E-mail address: marina.mosquera@urv.cat (M. Mosquera). lower Francolí river basin, $50 \mathrm{~m}$ above the Mediterranean Sea level. The area was formed during the late Early Pleistocene, and is currently dissected by the ravine of a seasonal stream.

Field work has been carried out since 2007 in three main localities: Pit 1, La Mina and El Forn. The sedimentary succession of Barranc de la Boella is $9 \mathrm{~m}$ thick and contains six lithostratigraphic units (Unit I to Unit VI, from bottom to top). The description and composition of each unit can be consulted in Vallverdú et al. (2014a, 2014b). To date, excavations have been carried out in Unit II of the three localities, while the other units have only been sampled. 


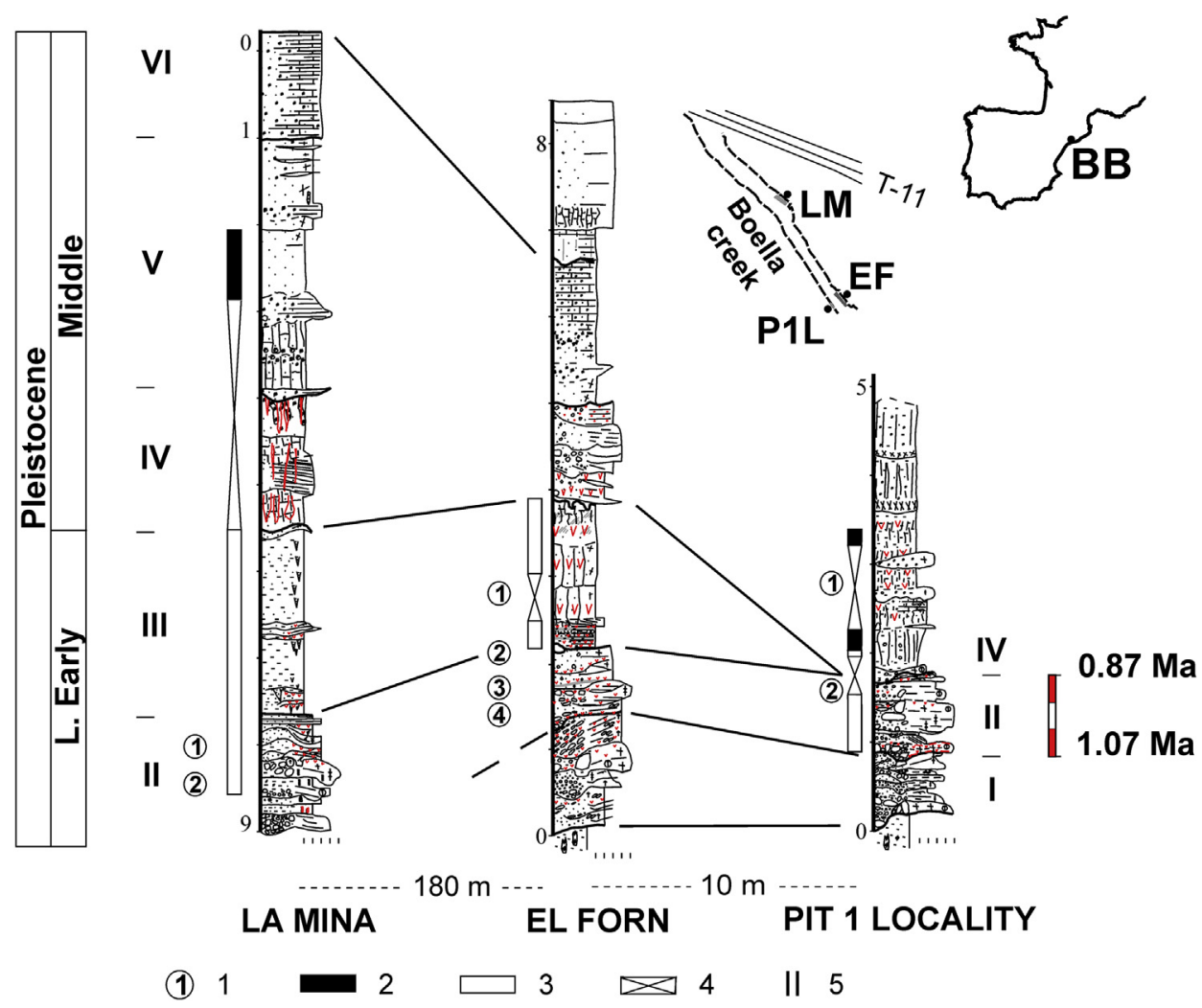

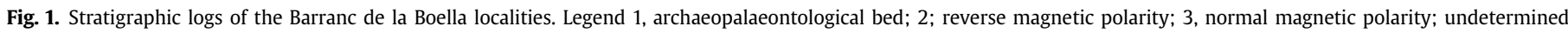
magnetic polarity; 5 , lithostratigraphic units.

Palaeomagnetic analyses indicate reverse polarity for Units II and III, biochronologically ascribed to the Matuyama chron. The Brunhes/Matuyama magnetic transition was recorded at the base of Unit IV. The Brunhes chron was identified in the upper part of Unit $\mathrm{V}$ at La Mina. The biostratigraphy of macro- and micromammals indicates a temporal span set between the late Early Pleistocene and the early Middle Pleistocene. The morphology of the Mimomys savini teeth samples from the top of Unit II at all three localities, as well as the presence of Victoriamys chalinei in El Forn and La Mina, situate the occupations between the top of the Jaramillo subchron (0.99 Ma) until shortly after the Brunhes-Matuyama transition at $0.78 \mathrm{Ma}$ (Lozano-Fernández et al., 2013, 2014), confirming the magnetostratigraphic data (Vallverdú et al., 2014a).

Cosmogenic analyses were conducted in Units I and II in El Forn and La Mina (Vallverdú et al. 2014a). The dates provided for Unit II support the lithostratigraphic correlation between the La Mina and El Forn localities, and indicate a minimum precise radiometric average date of $1.00 \pm 0.068$ Ma. A reliable geochronological age for the lithic assemblages found within Barranc de la Boella Unit II, constrained by magnetostratigraphic correlation, indicates late Early Pleistocene or late Matuyama chron $(0.96-0.78 \mathrm{Ma})$. The three localities would be pericontemporary.

\section{The archaeological assemblages}

\subsection{La Mina}

The locality of La Mina (Fig. 2) has a stratigraphic sequence of $9 \mathrm{~m}$ divided into six units named from bottom to top. Units III to VI have only been sampled; Units IV and V (Brunhes) yielded three 3 stone tools; and Unit VI (Brunhes) yielded 13 artefacts, including one centripetal core, one carenated denticulate, 10 simple flakes and broken flakes, and one Levallois flake.

Unit II of La Mina (Matuyama) about $2 \mathrm{~m}$ thick contains three archaeological levels. Approximately $40 \mathrm{~m}^{2}$ of its surface area is being excavated. Given that the excavation is still in progress, all of the artefacts collected so fat are discussed here in order to present a coherent view.

The assemblage of La Mina Unit II has yielded so far 80 lithic pieces and 711 faunal remains mainly belonging to Mammuthus meridionalis, Bovini sp., Hippopotamus antiquus, Equus cf. stenonis, Megaloceros savini, Cervus sp., and Dama cf. vallonetensis (Vallverdú et al., 2014a). There are also some remains of canids, ursids and medium-sized felids, a large felid which has yet to be determined, as well as Macaca sylvanus. The Hyaenidae are represented by more than 25 coprolites. Chemical alteration of the bones has prevented the identification of cut-marks, but percussion marks have been documented (Pineda et al., 2014), as has carnivore activity OSC.

The lithic assemblage (Table 1 ) is made from chert, schist, sandstone, quartz, porphyr, quartzite, and granite. All the varieties and formats of raw materials used at the Barranc de la Boella occupations are local and were easily available from the Quaternary deposits on which the fluvio-deltaic formation was developed. Metamorphic materials dominate, particularly different varieties of schist, but there is also an abundance of igneous rocks, such as granite, vein quartz and, to a lesser extent, sedimentary materials, such as chert and sandstone. A precise study on the sizes and proportions of the available raw materials at each occupation is still in progress. 
Table 1

Raw materials and lithic artefacts at Unit II of La Mina (Barranc de la Boella).

\begin{tabular}{|c|c|c|c|c|c|c|c|c|c|c|c|}
\hline $\begin{array}{l}\text { La Mina } \\
\text { Unit II }\end{array}$ & Hammerstones & $\begin{array}{l}\text { Percussive } \\
\text { material }\end{array}$ & Chopper-cores & $\begin{array}{l}\text { Small tools on pebble } \\
\text { (denticulate and chopper) }\end{array}$ & $\begin{array}{l}\text { Cores and } \\
\text { core frag. }\end{array}$ & $\begin{array}{l}\text { Retouched } \\
\text { flakes }\end{array}$ & Flakes & $\begin{array}{l}\text { Broken } \\
\text { flakes }\end{array}$ & $\begin{array}{l}\text { Flake } \\
\text { fragments }\end{array}$ & $\begin{array}{l}\text { Knapping } \\
\text { fragments }\end{array}$ & Total \\
\hline Chert & & & & 1 & 5 & 6 & 23 & 10 & 10 & 6 & 61 \\
\hline Schist & 1 & 3 & 2 & 1 & & & & & & & 7 \\
\hline Sandstone & & 3 & & & & 1 & & & & & 4 \\
\hline Quartz & & 2 & & & & & 1 & & & & 3 \\
\hline Porphyry & & 1 & 1 & & & & & & & & 2 \\
\hline Quartzite & & 1 & 1 & & & & & & & & 2 \\
\hline Granite & 1 & & & & & & & & & & 1 \\
\hline Total & 2 & 10 & 4 & 2 & 5 & 7 & 24 & 10 & 10 & 6 & 80 \\
\hline
\end{tabular}

The assemblage contains two hammerstones with the expected concentrated pitting limited to one extremity, indicating lithic knapping. There are also 10 cobbles and broken cobbles with less diagnostic marks suggesting percussion activities (hereafter, "percussion material", Mora and de la Torre, 2005; Roche et al., 2009; Moncel et al., 2013). The assemblage also yielded four choppercore forms, five cores and core fragments, two small tools on pebbles, seven retouched flakes, and 50 flakes, broken flakes and flake fragments (Fig. 3).

The percussion material stands out at La Mina as well as at the other localities at Barranc de la Boella. It consists of mainly schist and sandstone cobbles, which may have been used for hard striking; some of them are broken, some have slight end-shaping, but all of them show chips and shards on their ends, likely due to use (Fig. 4). The locality of La Mina has the highest proportion of percussion material.

The four chopper-core forms from La Mina exhibit modification on no more than half the perimeter. Choppers and chopping-tools are always difficult to distinguish from cores. Therefore, we use the chopper-core terminology (Texier et al., 2006) and only pieces made on flat cobbles with a convex, regular shaped edge have been classified as choppers or chopping-tools, depending on whether they were unifacially or bifacially modified. Furthermore, choppercores are not classified simply as cores, because at Barranc de la Boella localities they are usually less exploited than the chert-cores. There are very few non-chert flakes and no non-chert retouched
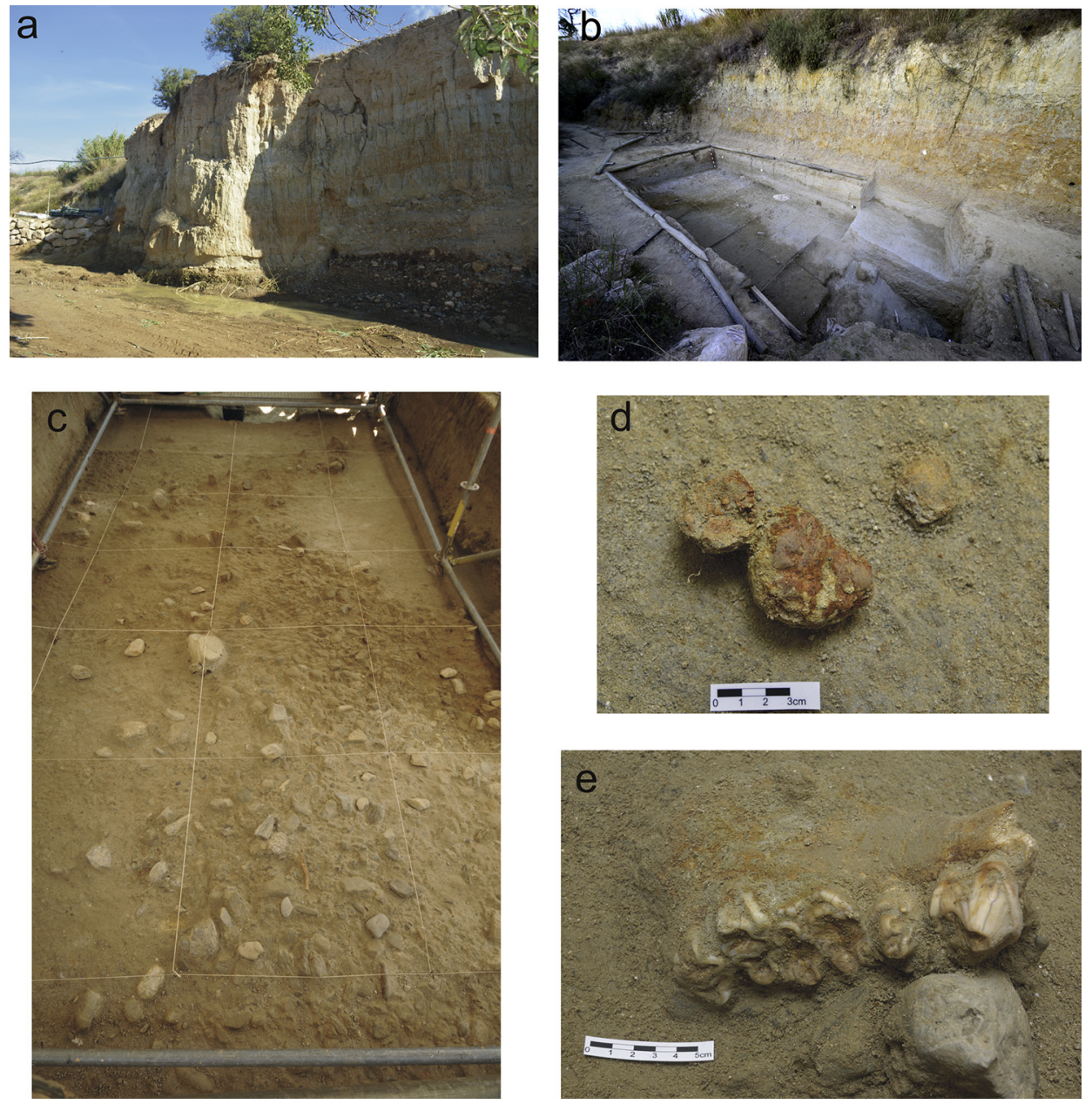

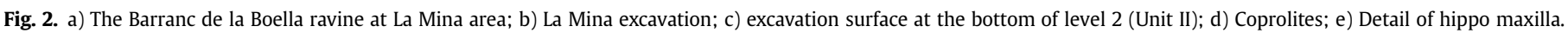




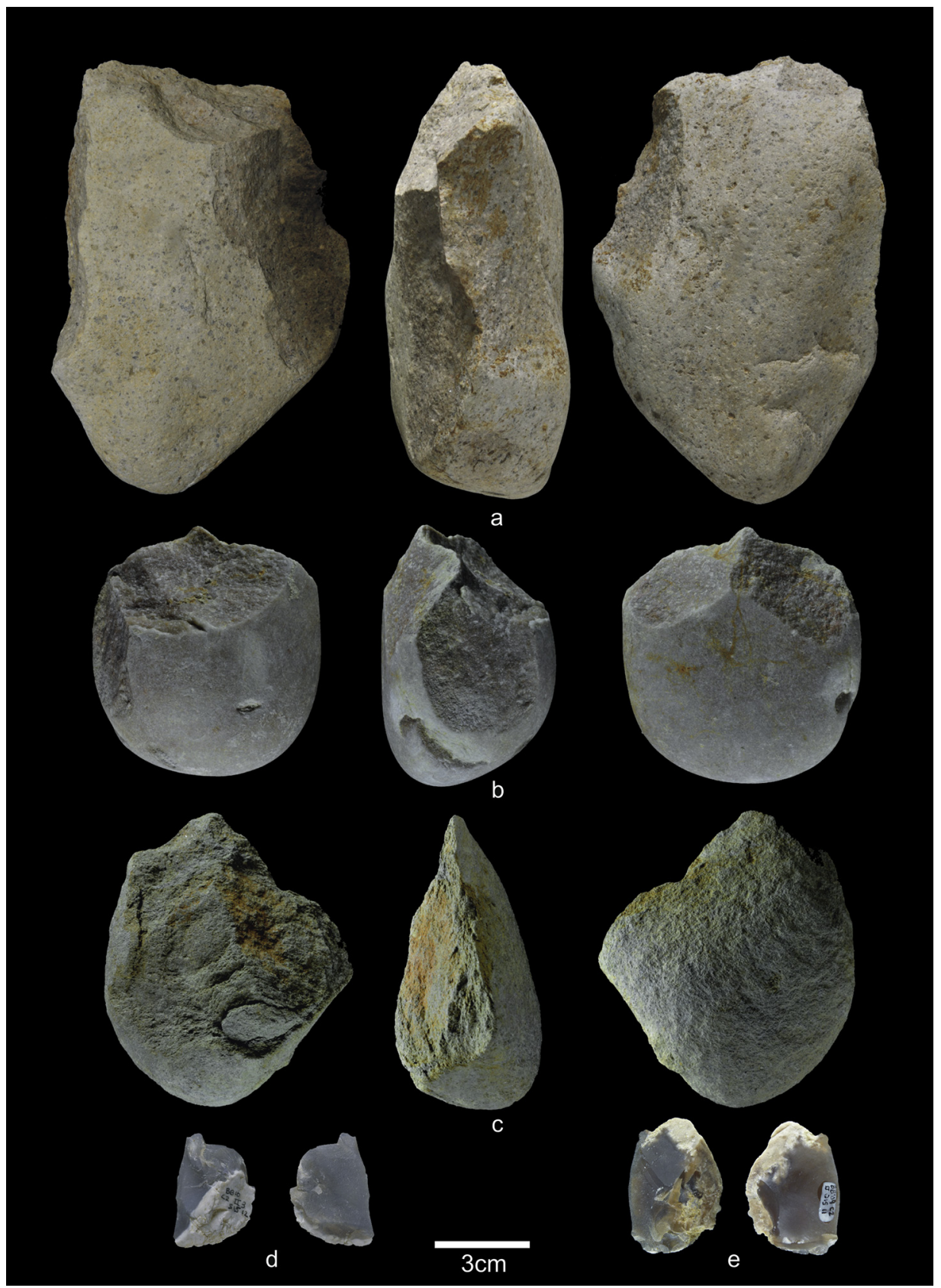

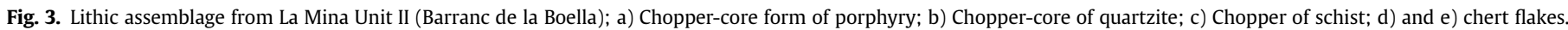

flakes in the archaeological assemblages, which could suggest that non-chert knapping products were not particularly appreciated for retouch or use. This leads us to suggest that these chopper-like forms were most likely tools rather than cores, but further investigation is needed to confirm this matter. The average size of the chopper-cores from La Mina is less than $10 \mathrm{~cm}$, except for one porphyr item.

All of the clear cores are of chert, as well as more than $95 \%$ of their products (flakes, broken flakes, fragments and retouched flakes - as blanks once detached from a core). The techniques used for extracting flakes from the cores are often simple and the removals are scarcely invasive, as demonstrated by the few scars identified on the cores. Although the centripetal method seems already to be present at La Mina (one core fragment), the unipolar method dominates, both unifacial and bifacial. The unipolar method consists of striking one side of a support from a single platform (cortical or prepared) maintaining an angle of close to $90^{\circ}$ with the extraction surface. The core was not rotated, and the blows were given successively next to and behind each last removal.

Simple flakes mainly exhibit non-cortical unifaceted butts; they are non-cortical or semicortical with two or three scars on their dorsal surfaces. The average size for the 23 complete flakes is $28 \times 28 \times 10 \mathrm{~mm}$, with a maximal size of $55 \times 56 \times 22 \mathrm{~mm}$ and a minimum of $9 \times 7 \times 5 \mathrm{~mm}$.

The small tools were mostly made by retouching chert flakes into carenated denticulates and notches. The average size of the five complete retouched flakes is $35 \times 35 \times 14 \mathrm{~mm}$. Retouch is light, with one generation of removals, and limited to short segments of the edges. Half of the pieces were retouched from the ventral surface and half from the dorsal surface. Most retouched flakes have 


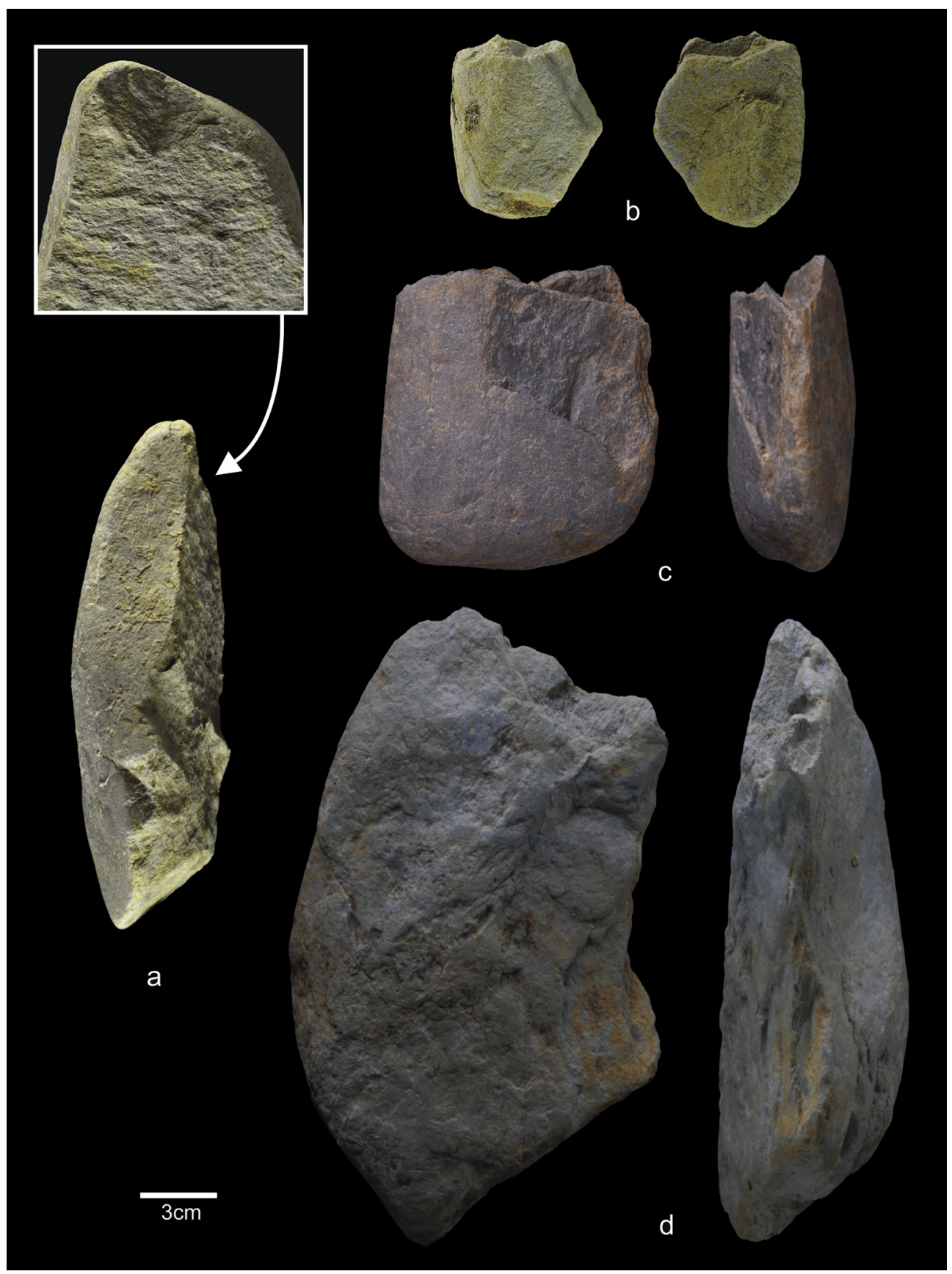

Fig. 4. Percussive material of schist from a) Pit 1; b) La Mina; c) and d) El Forn (Barranc de la Boella).

either three or five dorsal removals. There are two interesting tools made by marginal shaping on a small schist pebble (chopper?) and a small chert blank (abrupt denticulate). Both tools are smaller than $65 \mathrm{~mm}$. One conjoining lithic set was found between a broken chert flake and a flake fragment, located less than $20 \mathrm{~cm}$ from one another.

\subsection{El Forn}

The locality of El Forn (Fig. 5) is $180 \mathrm{~m}$ to the south of La Mina. It has a stratigraphic sequence of $8 \mathrm{~m}$, in which Units II and III (Matuyama) have been individualized, as well as an undifferentiated group of Units IV, V and VI (Brunhes). Approximately $68 \mathrm{~m}^{2}$ of the surface area of Units II and III have been excavated.
Unit III has one archaeological level (level 1), and Unit II contains archaeological levels 2, 3 and 4. Unfortunately, distinguishing level 2 from level 3 in some areas of the excavation has proven to be quite difficult, so we decided to group them into levels 2 and 3 in order to present a non-biased description of the lithic assemblage.

The level 1 (Unit III) record is made up of 178 faunal remains and seven lithic items: two schist hammerstones, one schist cobble with percussion marks, and one chert core, two chert flakes and one broken chert flake.

Levels 2 and 3 (Unit II) have yielded 306 faunal remains and 100 lithic items. The fauna includes: Mammuthus meridionalis, Megaloceros savini, Cervus sp., Dama cf. vallonetensis, Equus sp., Bovini sp., Hippopotamus antiquus, Stephanorinus hundsheimiensis, Ursus sp., and Castor sp. (Vallverdú et al., 2014a). The fossils from El Forn are 

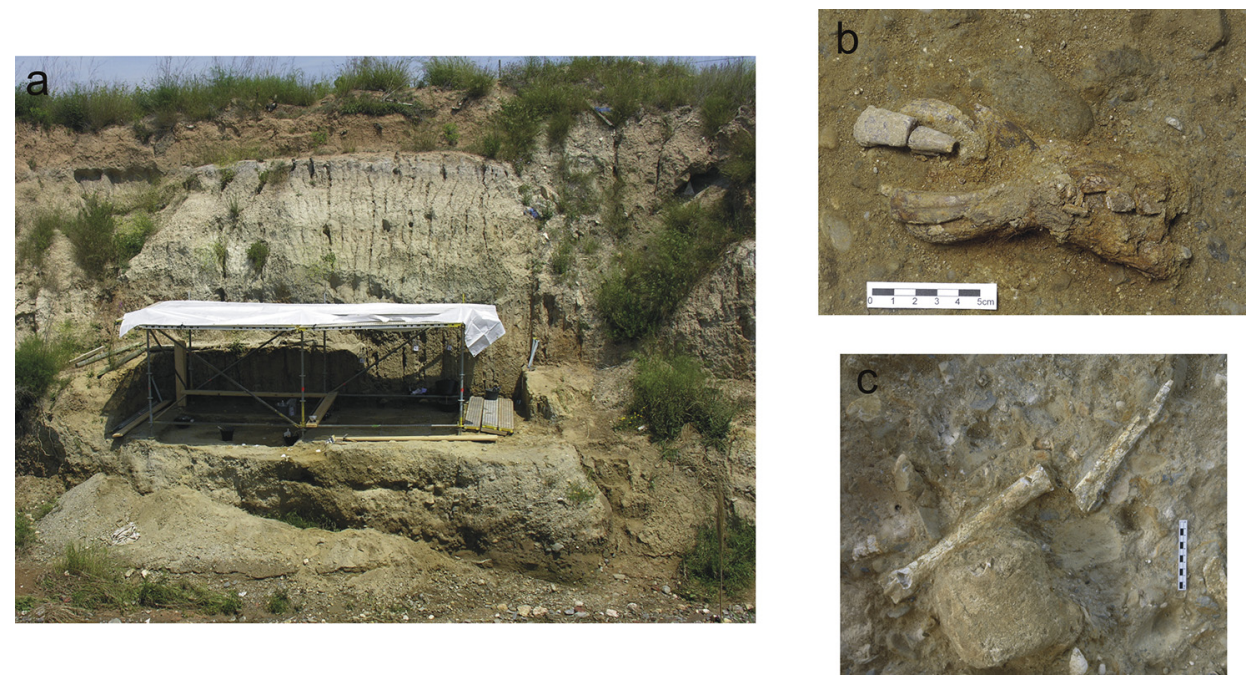

Fig. 5. a) The site of El Forn (Barranc de la Boella); b) mandible of Equus sp. (Unit II); c) radius and metapodial of cervidae (Unit II).

poorly conserved compared to those from La Mina. However, the activity of large carnivores has been identified in all of the levels. For instance, a long mammoth bone with "scooping-out" of the epiphyses has been recovered, suggesting hyena activity in this Early Pleistocene environment.

The lithic assemblage of levels 2 and 3 from El Forn (Figs. 6 and 7) (Table 2) is made of chert, schist, quartz, quartzite, sandstone, and granite. There are four hammerstones with knapping marks, one of which is also a chopper-core form. All of them were selectively chosen on the best quality and hardest varieties of quartzite, schist and quartz. The assemblage also includes nine broken cobbles, identified as percussion material, and two other cobbles that are extremely altered. Most of them are large flat schist cobbles. There are also four medium-large tools: one becked tool, two choppers, and one cleaver-like tool on a very fine quality and hardwearing variety of schist (Fig. 7). This tool has been made on a massive unprepared flake, possibly a split cobble, using one generation of very invasive removals. average dimensions are $35 \times 31 \times 10 \mathrm{~mm}$, with a maximal size of $50 \times 86 \times 14 \mathrm{~mm}$ and a minimum of $17 \times 17 \times 3 \mathrm{~mm}$. A total of 23 broken flakes, flake fragments and angular fragments have been recovered. The small tools are represented by four chert denticulates, one chert becked tool (size: $44 \times 42 \times 17 \mathrm{~mm}$ ), and one notch on a small schist pebble. Retouched flakes have three, four and five dorsal removals - so more than simple flakes, and retouch was mainly effectuated on the dorsal edges (direct retouch).

This record clearly indicates a distinct, differential use of raw materials, with chert selected for the production of small-tools and other rocks chosen for large, heavy-duty tools. No refits have been found so far at El Forn, even though the material is very fresh and the site has yielded the highest number of cores and flaking products.

Level 4 (Unit II), the oldest level, yielded 234 faunal remains and seven lithic items. This lithic assemblage seems to be similar to that analysed in levels 2 and 3, and contains one piece of schist per-

Table 2

Raw materials and lithic artefacts at El Forn Levels 2 \& 3 (Barranc de la Boella).

\begin{tabular}{|c|c|c|c|c|c|c|c|c|c|c|c|c|c|}
\hline $\begin{array}{l}\text { El Forn } \\
\text { levels } 2 \& 3\end{array}$ & Hammerstones & $\begin{array}{l}\text { Percussive } \\
\text { material }\end{array}$ & Choppers & $\begin{array}{l}\text { Large tool on } \\
\text { flake - Cleaver-like } \\
\text { tool }\end{array}$ & Chopper-cores & Cores & $\begin{array}{l}\text { Small tool } \\
\text { on pebble } \\
\text { (notch and bec) }\end{array}$ & $\begin{array}{l}\text { Retouched } \\
\text { flakes }\end{array}$ & Flakes & $\begin{array}{l}\text { Broken } \\
\text { flakes }\end{array}$ & $\begin{array}{l}\text { Flake } \\
\text { fragments }\end{array}$ & $\begin{array}{l}\text { Knapping } \\
\text { fragments }\end{array}$ & Total \\
\hline Chert & & & & & & 7 & & 6 & 44 & 8 & 5 & 7 & 77 \\
\hline Schist & 1 & 7 & 2 & 1 & & & 1 & & & 1 & & & 15 \\
\hline Quartz & 1 & 1 & & & & 1 & & & & & & 2 & 5 \\
\hline Quartzite & 1 & & & & 1 & & & & & & & & 2 \\
\hline Sandstone & & 1 & & & & & & & & & & & 1 \\
\hline Granite & & & & & & & 1 & & & & & & 1 \\
\hline Total & 4 & 9 & 2 & 1 & 1 & 8 & 2 & 6 & 44 & 9 & 5 & 9 & 100 \\
\hline
\end{tabular}

This level also contains one quartz and seven chert cores. Two of the largest cores (one of chert and one of quartz) exhibit unipolar longitudinal method, but very few scars. Therefore, these were probably supports tested and ultimately abandoned due to the presence of impurities and fissures. The rest are good quality chert cores with considerable standardization in flaking. They have been reduced using unipolar longitudinal $(n=4)$ and bipolar opposing $(\mathrm{n}=2)$ flaking.

Again, around $95 \%$ of the products are of chert. The complete flakes $(\mathrm{n}=44)$ are more regular in shape and bigger in size than at La Mina, but their main technical features are similar. Their cussion material, one chert core with bifacial centripetal knapping, three flakes, one broken flake, and one chert fragment.

\subsection{Pit 1 locality}

The Pit 1 locality is located at a distance of $10 \mathrm{~m}$ across from El Forn, on the other side of the ravine. It was the first locality to be excavated, and it has the shortest stratigraphic sequence of all the Barranc de la Boella sites ( $3 \mathrm{~m}$ ), due to erosive events, which have eliminated Units III, V and VI. An area of approximately $13 \mathrm{~m}^{2}$ of this locality has been excavated. 


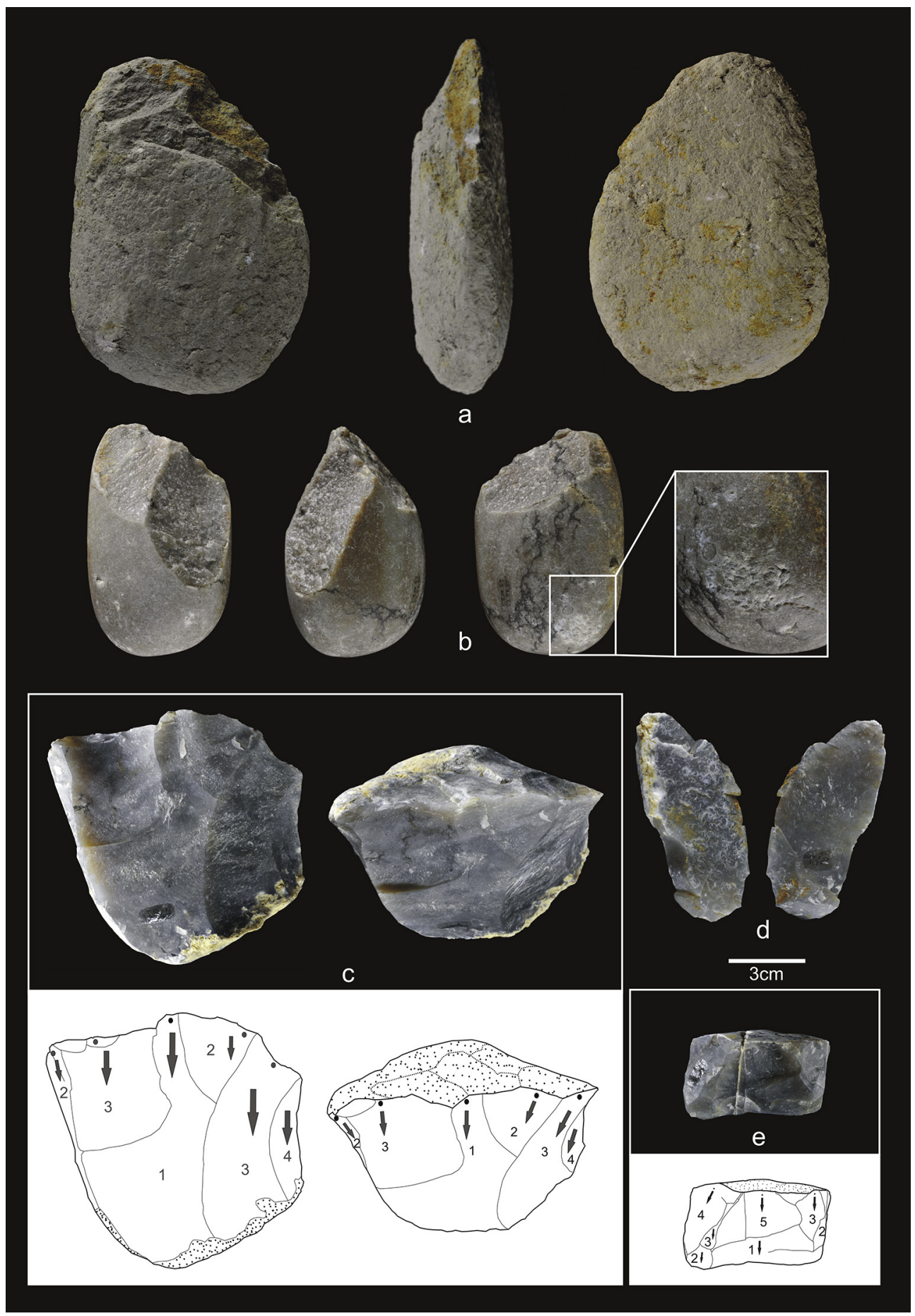

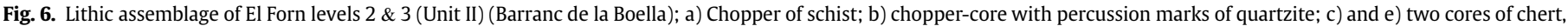
and their diacritic scheme; d) flake of chert.

Unit IV (Brunhes) contains archaeological level 1 with four faunal remains and 17 lithic pieces, including two broken cobbles of schist and quartzite, identified as percussion material, 13 simple and broken chert flakes, and two broken flakes of quartz and schist.

Unit II (Matuyama) is made up of levels 2 and 3. Each of these levels has yielded two Mammuthus meridionalis tusks, as well as other faunal remains from this and other species.

Level 2 yielded 549 faunal remains, most of which belong to a single young-adult individual of Mammuthus meridionalis, although a few remains of Dama cf. vallonetensis, Equus sp, and one lamella of a neonate mammoth have been recovered as well (Vallverdú et al., 2014a). The lithic assemblage (Table 3) accompanying these animals comprises 125 pieces in chert, schist, quartz, sandstone, granite and quartzite. This level is consistent with a butchering site (Leakey, 1971; Isaac, 1978; Haynes, 1991), in which the remains of the adult elephant, as well as the tools, were moved and arranged in particular positions, over the surface of the occupation (Fig. 8) (Mosquera et al., accepted). Unfortunately, at least half of the 

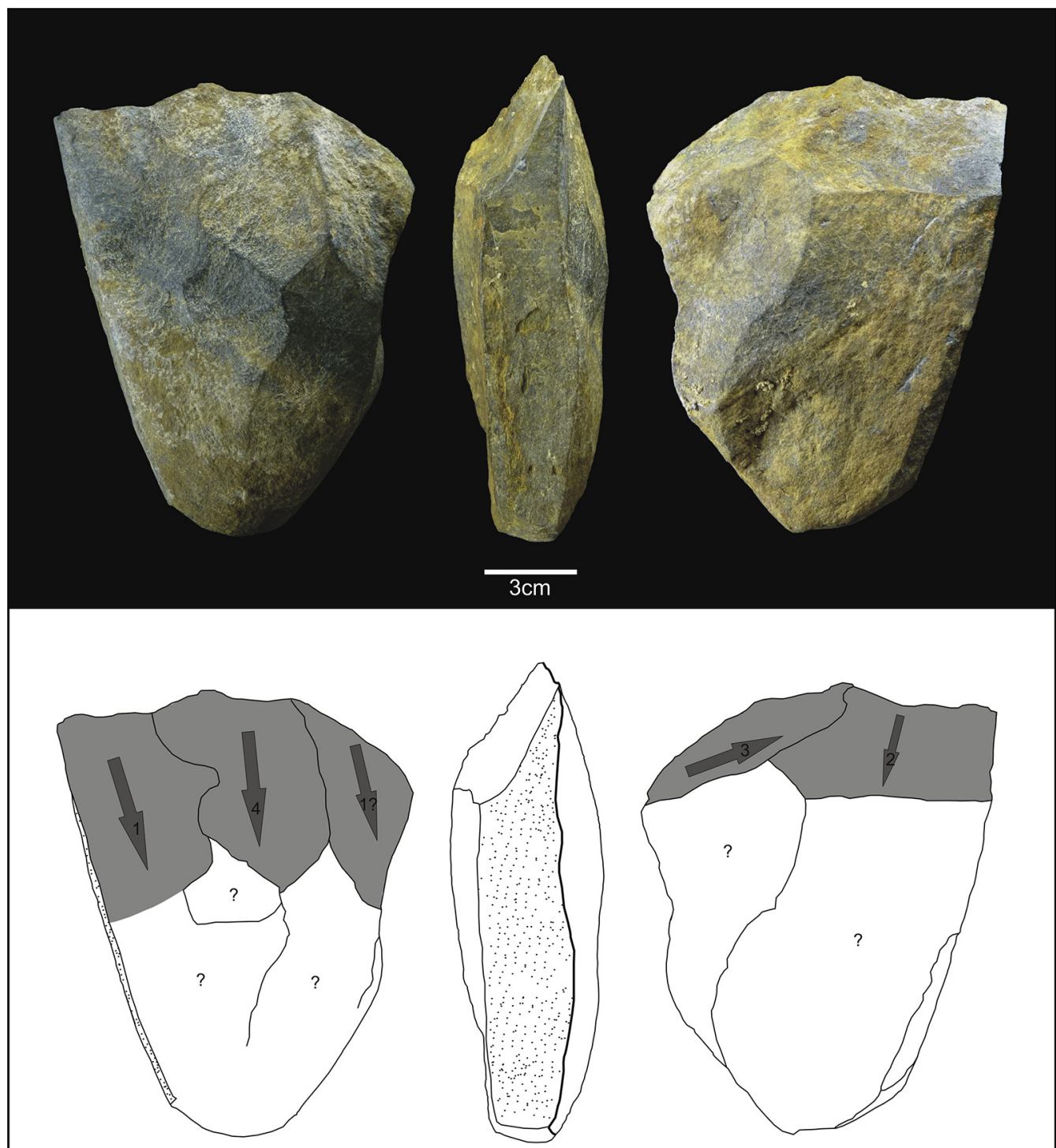

Fig. 7. El Forn level 2 (Barranc de la Boella): Cleaver-like tool made of schist, and diacritic scheme.

occupation floor is still pending excavations, which are expected to be completed in the near future. This is the oldest butchering site known in Europe, after the Upper level of Fuente Nueva 3 (Espigares et al., 2013). The lithic assemblage is composed of three hammerstones, seven cobbles as percussion material, one large cutting tool (a pick) of hard-wearing schist, three cores, eight retouched flakes, and 103 flakes, broken flakes and fragments (Fig. 9).
Like the cleaver-like tool from El Forn, the pick from Pit 1 has been made of the same very good and hard-wearing variety of schist, using an unusually massive and unprepared flake, which may be a split cobble. However, the configuration of the pick is more complex, with one generation of very invasive removals and a second generation of removals to shape the left side (Fig. 10).

The cores were only slightly worked by means of unipolar longitudinal and centripetal knapping methods. Simple flakes are

Table 3

Raw materials and lithic artefacts at Pit 1 Level 2 (Barranc de la Boella).

\begin{tabular}{|c|c|c|c|c|c|c|c|c|c|c|}
\hline Pit 1 Level 2 & Hammerstones & $\begin{array}{l}\text { Percussive } \\
\text { material }\end{array}$ & $\begin{array}{l}\text { Large tool on } \\
\text { flake - pick }\end{array}$ & Cores & Retouched flakes & Flakes & Broken flakes & Flake fragments & $\begin{array}{l}\text { Knapping } \\
\text { fragments }\end{array}$ & Total \\
\hline Chert & & & & 1 & 8 & 40 & 18 & 17 & 13 & 97 \\
\hline Schist & & 3 & 1 & 1 & & 1 & 1 & & 3 & 10 \\
\hline Quartz & & & & & & 4 & & 1 & 5 & 10 \\
\hline Sandstone & 1 & 2 & & 1 & & & & & & 4 \\
\hline Granite & 1 & 2 & & & & & & & & 3 \\
\hline Quartzite & 1 & & & & & & & & & 1 \\
\hline Total & 3 & 7 & 1 & 3 & 8 & 45 & 19 & 18 & 21 & 125 \\
\hline
\end{tabular}




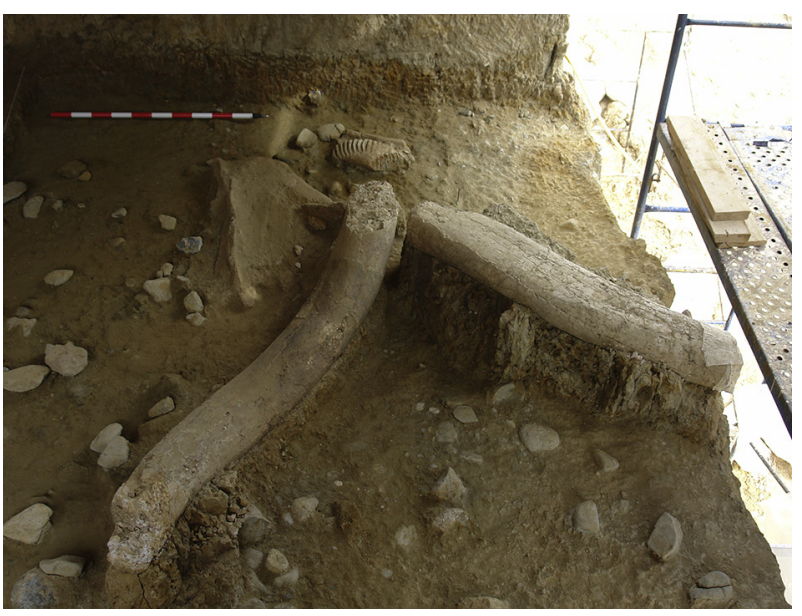

Fig. 8. Excavation of the remains of Mammuthus meriodionalis at level 2 (Unit II) of Pit 1 (Barranc de la Boella).

similar to the other localities, with an average size of $29 \times 28 \times 9 \mathrm{~mm}$ (maximum: $76 \times 55 \times 12 \mathrm{~mm}$; minimum: $10 \times 8 \times 2 \mathrm{~mm}$ ). The small tools are mainly notches and denticulates, selectively produced on some of the largest chert flakes (average size: $52 \times 50 \times 20 \mathrm{~mm}$ ).

The chert assemblage is made up of nine varieties, presumably belonging to nine operative chains. Among them, three groups stand out: two of them because they contain the finest flakes with the longest sharp edges in Barranc de la Boella, and exhibit compelling evidence of use-wear derived from butchering activities; the third group because of its thick and robust flakes, comprising six of the eight retouched flakes from this level. These retouched flakes oddly show very little use-wear evidence. Interestingly, the differential manufacture techniques used to make these tools could suggest that they represent the final knapping products of two different hominins, each of them with particular savoir-faire or tasks to be carried out.

SEM microwear analyses carried out on a sample of 20 simple and retouched chert flakes showed that their surfaces are absolutely fresh, well preserved, with no natural edge microflaking or rounding (Mosquera et al., accepted). We found clear butchery usewear traces on at least seven flakes, and occasional and less conclusive use-wear on another three retouched tools.

Thirteen refits and conjoining lithic sets have been identified, involving 30 pieces: 28 of chert and two of sandstone. Most of them are conjoins ( $\mathrm{n}=9 ; 19$ pieces); that is, fragments broken during flaking that fit together. Only four groups are refits (11 pieces); that is, consecutive pieces detached during knapping and retouching sequences that fit together (Fig. 11). The shortest distance between conjoining lithic sets is $1 \mathrm{~cm}$ and the longest belongs to a knapping (refit) sequence, separated by $230 \mathrm{~cm}$.

The last archaeological level excavated in Unit II of Pit 1 is level 3, which yielded 27 faunal remains (Mammuthus meridionalis, Equus sc. stenonis and Dama sp. vallonetensis) and seven lithic items: one fragment of a chert core, one (possible) schist pick, one denticulate, one very eroded notch, one flake and one flake fragment, and a cobble with percussion marks.

\section{Discussion}

\subsection{Significance of Barranc de la Boella site}

In the European Early Pleistocene contexts, one factor clearly stands out at the Barranc de la Boella site: the presence of two large bifacial tools - a cleaver-like tool and a pick. Other features of the site are also particularly noteworthy: 1) No large cutting tools have been recovered at La Mina, although it has yielded chopper-cores (only one $>10 \mathrm{~cm}$ ); 2) Choppers and one cleaver-like tool have been found at El Forn; and 3) No chopper-cores have been identified at Pit 1 , although a pick has been recovered at this locality, technologically connecting it to El Forn, which is in very close geographic proximity $(10 \mathrm{~m})$.

The remainder of the lithic assemblages are extremely similar in composition in all three localities: all of them have some retouched tools, mainly denticulates and notches; all of them have "percussion material", that is cobbles and broken cobbles with chips and shards on their ends, likely due to hard striking, perhaps against large and long bones to access the marrow. In general, they were selected among poor quality materials, small and globular cobbles at La Mina, and very large, flat and soft schist cobbles at Pit 1 and, particularly, El Forn. Based on our experimentation, this raw material knaps easily, but also breaks easily, which may explain why it was not used for knapping or shaping large tools at any of the localities. Instead, large tools like choppers and large cutting tools were often made using the most resistant and hardest raw materials: quartzite, hard-wearing schist, and porphyr. In contrast, chert was used exclusively to produce flakes and retouched flakes at all three localities.

In summary, the three localities yielded very similar lithic technological records with regard to the composition of the assemblages, the knapping methods involved, and the differential use of the raw materials, which seem to be in all cases of local origin. However, La Mina lacks large cutting tools and its percussion material is smaller and more globular. El Forn and Pit 1 yielded a cleaver-like tool and a pick, respectively, in association with a set of finely flaked chert flakes. There are no qualitative differences between them, beyond the longer sizes of the El Forn percussion material and the absence of chopper-cored in the Pit 1 locality. Furthermore, El Forn and La Mina yielded a tool type produced by "retouching" or slightly shaping very small pebbles into becked tools and abrupt denticulates.

Thus, the most outstanding difference among the three localities - the absence of large cutting tools at La Mina - may simply be a coincidence or it may reflect the particular occupational characteristics of this site. This raises some questions: To which technocultural adscription may we ascribe the lithic assemblages of La Mina, El Forn and Pit 1 localities? If Acheulean, where did this technology come from?

In our view, at least El Forn and Pit 1 represent a European Early Acheulean, perhaps the oldest Acheulean documented in Europe to date (Vallverdú et al., 2014a, 2014b). This conclusion is based on the presence of large, bifacially shaped tools - and even unifacially worked picks and handaxes (Beyene et al., 2013) - which mark the appearance of this technology in Europe. Although the Acheulean is more than the presence of these large tools (see 3.3), only two of these instruments have been reported in the European Early Pleistocene: one handaxe from Estrecho de Quípar (Murcia, Spain) and another from Solana de Zamborino (Granada, Spain) (Scott and Gibert, 2009). However, the chronology of both of these sites has been strongly contested by some authors (Jiménez-Arenas et al., 2011).

Additionally, the crude method in which both the pick and the cleaver-like tool at Barranc de la Boella sites were produced resembles the Developed Oldowan B (Leakey, 1971) and/or the Early Acheulean (de la Torre, 2004) of Olduvai (Tanzania), as well as the lower levels of Ubeidiya (Israel) (Bar-Yosef and Goren-Inbar, 1993; Bar-Yosef and Belfer-Cohen, 2001). Both in the case of the pick and the cleaver-like tool the support consists of half of an unprepared cobble, with very marked bulbs - therefore, technically classifying 


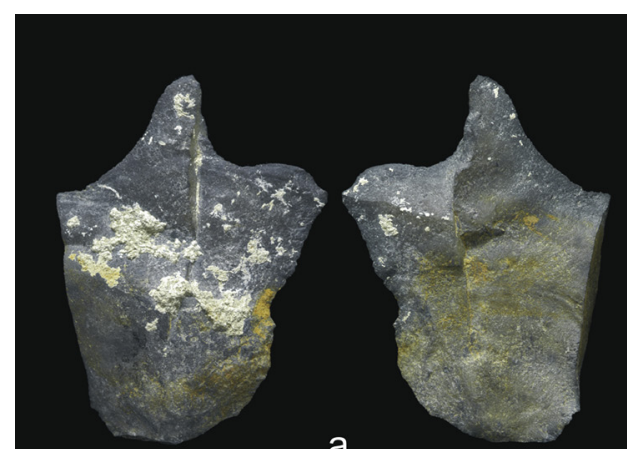

a

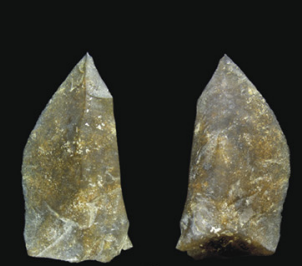

C

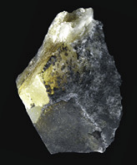

e
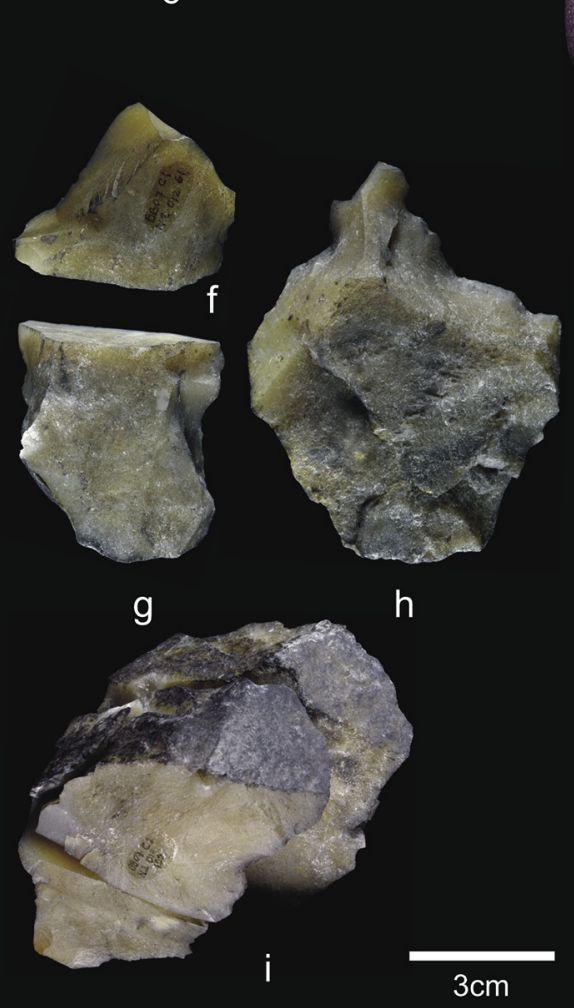

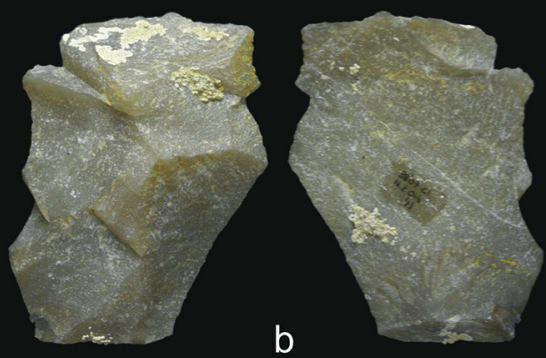

b
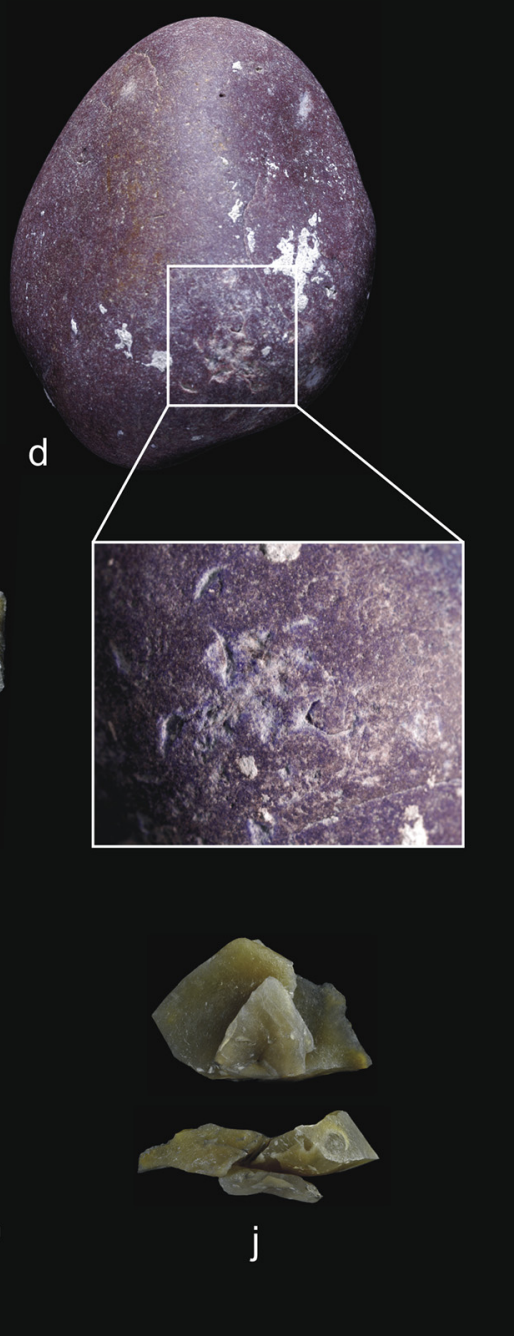

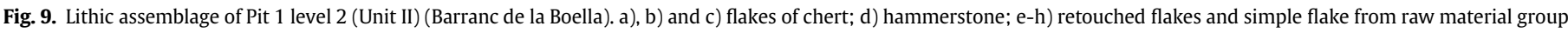
6 , conforming the refit num. 7 (i); j) Flakes and broken flake from raw material group 7 , conforming refit num. 8.

them as flakes - but so massive that it is not possible to distinguish them from a split cobble. Also, the lack of fine, accurate finishing of the pick from Pit 1 and the cleaver-like tool from El Forn may point to an old technology.

In this sense, and according to the chronology of this site, these assemblages may be one of the older (or the oldest) expressions of the Acheulean in Europe, which leads us to question how it evolved, emerged, or arrived on the subcontinent, and specifically, in this Mediterranean area.

The Acheulean of Barranc de la Boella may have come from elsewhere, perhaps the Near East or Africa, given the presence of picks and cleavers in both areas -as well as the presence of choppers and chopper-cores-, and particularly considering the manner in which the former were produced.

"Emergence" usually means a step forward in an evolutionary process that marks a qualitative threshold. Emergent events generally rely on previous advances and experiences, as total and sudden appearances are rather rare in historical processes. Sudden appearances constitute inventions, and of course the Acheulean may have been invented two, three or several times. If this is the case, assemblages containing the background traits from which the technology developed would be difficult to find. 

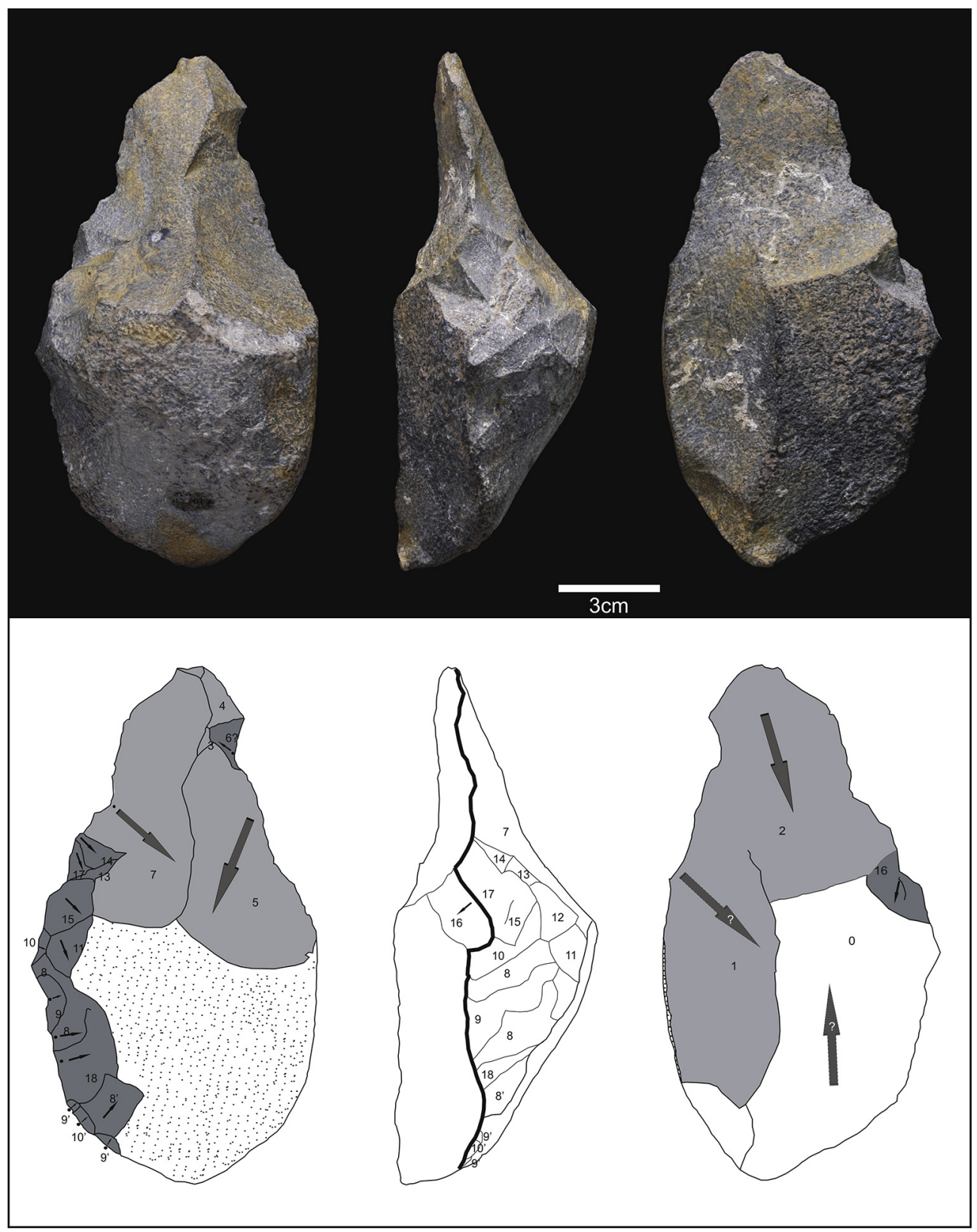

Fig. 10. Pit 1, level 2 (Barranc de la Boella): Pick made of schist and diacritic scheme.

Evolution means that the new technology relies on a local foundation. Although it is very difficult to distinguish in practice, theoretically it is possible to state which features are developed and which are primitive in a technological assemblage. In the case of Barranc de la Boella, we should search for local pre-Acheulean assemblages from which this European Early Acheulean may have evolved. In order to ascertain if the Acheulean of Barranc de la Boella may have evolved from earlier local technologies, we need to know how to recognize this type of transition.

\subsection{Going back to Africa}

Interestingly, at Olduvai - the world's largest and most wellknown stratigraphic sequence-this transition is unclear. Actually, it looks like there is no way of finding a proper "transition" and the debate about the dichotomy between the Developed Oldowan and the Acheulean in Africa is still in progress. It has been the subject of numerous revisions and theoretical approaches (see de la Torre and Mora, 2005 for a synthetic review). The growing consensus favours the idea that the Developed Oldowan and the Acheulean are only different activity facies "linked to functional and/or paleoecological factors." (de la Torre and Mora, 2013), particularly related to landscape and raw material parameters (Kimura, 2002; de la Torre and Mora, 2013), that were influential at Olduvai as well as at other localities, such as Peninj (de la Torre, 2009; Díez et al., 2012).

A technical evolution between the Oldowan and/or Developed Oldowan and the Acheulean has also not been found at KonsoGardula, clearly Acheulean (Beyene et al., 2013), or at the complex of Lokalalei, with only core/flake technology (Roche et al., 2009). At Kokiselei (Roche et al., 2003) five sites make up the sequence, KS1 to KS5, located at a distance of up to $25 \mathrm{~km}$ from one another. Chronologically, KS4 represents the oldest known Acheulean, dated at 1.76 Ma (Lepre et al., 2011). It has yielded 167 lithic items including, "handaxes or proto-handaxes, picks and 


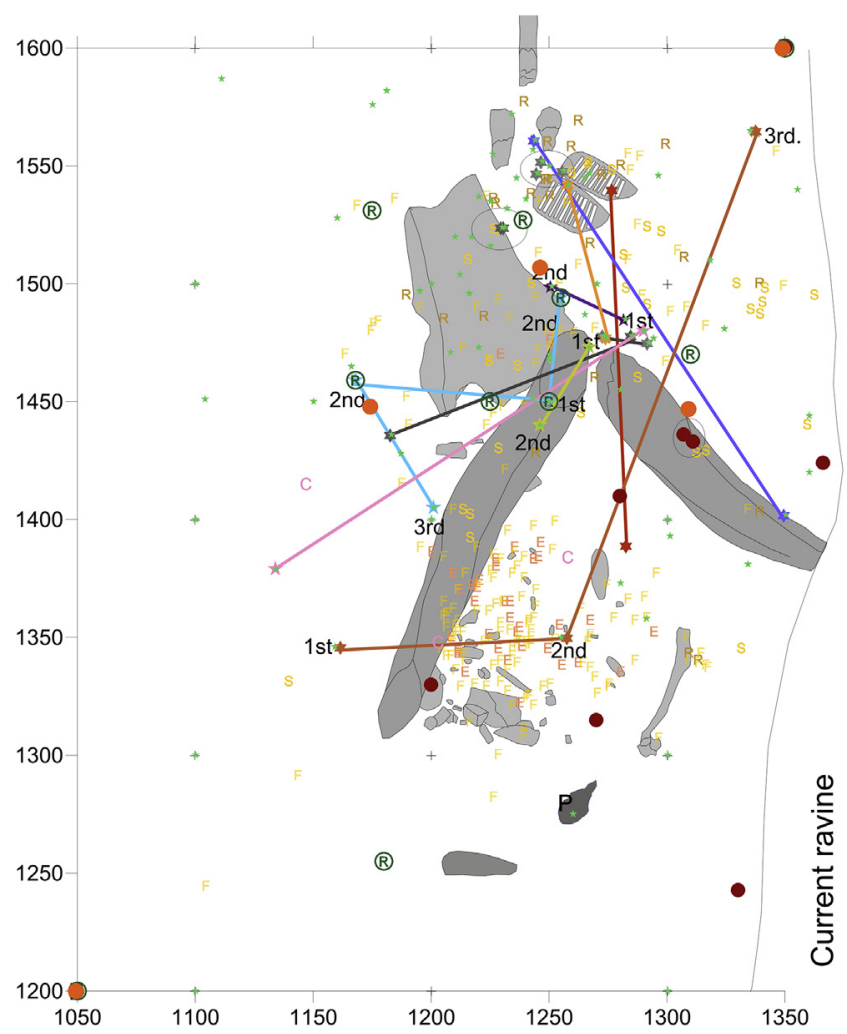

Fig. 11. Map of the excavation of the mammoth of Pit 1-level 2 (Barranc de la Boella), with the position of the faunal and lithic remains and the connection of conjoining and refitting lithic sets. C: Cores; ${ }^{\circledR}$ : Retouched tools; P: Pick; Red dots: Percussive material; Orange dots: Hammerstones; Green stars: Flakes; F: Flat bones; S: Skull bones; R: Ribs, E: Scapula fragments (For interpretation of the references to colour in this figure legend, the reader is referred to the electronic version of this article)

flakes, some of them very large, as are some of the cores" (Roche et al., 2003: 655).

Meanwhile, KS5, whose chronostratigraphic position situates it between the Oldowan of KS1 and the Acheulean of KS4, does not contain any of the large bifacial pieces that characterize KS4 (Roche et al., 2003). KS5 contains 2048 lithic pieces among which simple flakes and fragments represent around $90 \%$ of the assemblage, the remainder made up of 40 cores, several "galets taillés" (choppercores) (Texier et al., 2006), some slightly modified blocks and one trihedral form on cobble. According to Texier and colleagues, although the assemblage composition are similar at Kokiselei 5 and Lokalalei 2C (Roche et al., 2009), the former represents a Developed Oldowan -more evolved than Lokalalei 2C-, because of the knapping methods used and a better knowledge of the raw materials properties to better adapt the adequate technical solutions. However, concerning the Acheulean, Lepre et al. (2011) assert, "Moreover, co-occurrence of Oldowan and Acheulian artefacts at the Kokiselei site complex indicates that the two technologies are not mutually exclusive time-successive components of an evolving cultural lineage, and suggests that the Acheulean was either imported from another location yet to be identified or originated from Oldowan hominins at this vicinity." (Lepre et al., 2011: 82. our underscoring).

At Garba IVD (Ethiopia), dated c. $1.5 \mathrm{Ma}$, researchers recognized the Early Acheulean by the emergence of a new technical process focused on large flake production, "the preferential choices of different raw materials for different technical processes, a high level of productivity in small debitage and the absence of true façonnage in LCT manufacture", among others (Gallotti, 2013: 617).
Finally, at the Busidima Formation at Gona (Ethiopia) there are "abundant Early Acheulean crudely-made bifaces and picks estimated to be c. $1.6 \mathrm{Ma}$. ( . . . ) ... the evidence ( ... ) appears to favour a rapid technological transition from the Oldowan (Mode I) to the Acheulean technology (Mode II), much in the same way that the earliest sites at Gona mark an abrupt transition from no archaeological record to the presence of an archaeological record ..." (Semaw et al., 2009: 185-186).

Some studies have stressed that the Acheulean tool-making demands for higher levels of cognitive-brain developments than Oldowan techniques (Stout and Chaminade, 2007; Stout et al. 2008), and although these cognitive developments likely generalized along time setting, "the technology itself (the Acheulean) represents a clear discontinuity” (Semaw et al., 2009: 184).

\subsection{What Europe tells us}

Taking the African information into account, it is interesting to review what Europe might have to offer on the matter about a hypothetic evolution from the pre-Acheulean to the Acheulean technology. Particularly, it is interesting to review the sites with stratigraphic sequences covering the Early and the Middle Pleistocene, in order to fix the geographic and environmental variables as constant. It may then be possible to determine how technology evolved in those sites, if in fact it did. Unfortunately, very few of these sites exist in Europe: Kärlich (Germany), Korolevo (Ukraine), and Sierra de Atapuerca (Spain).

The site of Korolevo is not in fact a single sequence, and no extensive excavation of the area has been conducted. Instead, a set of trenches and pits have been used for sedimentary correlation. Koroloevo is on an ancient alluvial terrace ascribed to the Jaramillo episode. The stratigraphy is formed by alternating loess and palaeosoils that range from the Lower to the Upper Palaeolithic. Complexes VII and VIII have been dated to the Matuyama-Brunhes boundary, while Complex VI belongs to the Middle Pleistocene and has been dated to c. 500 ka (Koulakovska et al., 2010; Rocca, 2013). According to the review by Koulakovska and colleagues (2010), Complex VIII may be part of Complex VII, which has yielded a few items from the in situ artefact Excavation Area XIII. The assemblage consists of 33 pieces including one polyhedron, two core-like chunks, five chunk-flakes, five cores, 12 flakes, four chunks, one fragment, one chip, and two tools: a chopper and a bifacial secondary flaked tool. According to the authors, there are different modes of core reduction, but the simple unidirectional, parallel, and radial reduction using hard hammer flaking dominate. The authors classify this technology as Mode 1 . Meanwhile, the Acheulean assemblage of Complex VI is made up of around 1500 items produced through a variety of knapping methods, and comprised of cores, simple flakes, and retouched flakes, including points and sidescrapers. However, large-cutting tools and heavy-duty tools are absent (Rocca, 2013). Here, as in many other northern sites where large cutting tools are absent, the technological change from Mode 1 to Acheulean would be reflected in the appearance of wellstructured and varied knapping methods, well-standardized cores and flakes, and the appearance or diversification of retouched flakes. In summary, Korolevo has a Mode 1 assemblage at the Matuyama/Brunhes boundary (Complex VII), and an Acheulean assemblage at around $500 \mathrm{ka}$ (Complex VI), without large cutting tools, and with a gap of c. $300 \mathrm{ky}$ in between. Interestingly, this same gap also occurs at the Gran Dolina-Atapuerca site (Mosquera et al., 2013; Ollé et al., 2013).

Kärlich (Germany) also has two complexes (A and Ba) ascribed to the Jaramillo episode and the Matuyama/Brunhes boundary, respectively (Bosinski, 2006; Haidle and Pawlik, 2010). However, neither complex has yielded many pieces: "few potential artefacts, 
one pebble and a core" for Kärlich A (Haidle and Pawlik, 2010: 145) and a few more than 10 pieces for Kärlich Ba (Rocca, 2013). The next possible correlation is in level G, dated to MIS 14/13, with 14 cores and flakes of quartz and quartzite (Bosinski, 1996). Additionally, the site of Kärlich-Seeufer, belonging to the Middle Pleistocene and dated at $400 \mathrm{ka}$ (Gaudzinski et al., 1996) yielded a lithic assemblage of 146 pieces, mainly made of quartzite and quartz. The knapping methods used are well organized and the assemblage contains several handaxes. Again, there is a gap at Kärlich between the Matuyama/Brunhes transition and the first half of the Middle Pleistocene.

At Sierra de Atapuerca three sites, Sima del Elefante, Gran Dolina and Galería chronologically correlate with one another, comprising hominin occupations from $1.4 \mathrm{Ma}$ to c. $200 \mathrm{ka}$ (Bermúdez de Castro et al., 1999, 2011; Rosas et al., 2001; Carbonell et al., 2005, 2008; Rodríguez et al., 2011; Ollé et al., 2013). For our purposes, the most relevant information is that Sima del Elefante has a sequence of $25 \mathrm{~m}$, ranging from the Early Pleistocene to the late Middle Pleistocene, with a sedimentary gap after the beginning of the Middle Pleistocene (Rosas et al., 2006; Arnold et al., 2014). It has yielded a few lithic objects belonging to the hominin-bearing Early Pleistocene level TE9 and the older TE8 (De Lombera-Hermida et al., 2015). Gran Dolina has a stratigraphical sequence ranging from more than $1 \mathrm{Ma}$ until $200 \mathrm{ka}$. It has an archaeological (not palaeontological) gap between the last Early Pleistocene level (TD6) -with Mode 1 technology, according
Pleistocene: Sierra de Atapuerca, Korolevo and Kärlich, but none of them contain any level in which the possible evolution from Mode 1 to Mode 2 (or Acheulean) is visible. Actually, all of them have archaeological gaps between apparently continuous fossiliferous deposits (Gran Dolina and Kärlich) or between different localities in close geographic proximity (the complexes of Korolevo, Kärlich and K-Seefuer, Gran Dolina and Galería). Certainly, none of the European sites contains a single level reflecting a visible technological transition from Mode 1 to the Acheulean, which in turn has been interpreted as a possible European demographic/occupational gap between c. $900 \mathrm{ka}$ and $600 \mathrm{ka}$ (Mosquera et al., 2013).

A further point is to ascertain whether technologies such as those represented at Atapuerca-TD6, Kärlich Ba and Korolevo Complex VII (late Mode 1 from c. $900 \mathrm{ka}$ ) or even earlier European assemblages may have evolved into the Acheulean. However, the Acheulean in Europe has a highly problematic definition, given that many northern and eastern sites do not contain large cutting tools. In other works (Mosquera et al., 2013; Ollé et al., 2013), we studied the technical features of all of the lithic assemblages from Sierra de Atapuerca, and we extracted several technical parameters that we consider significant for characterizing each technology represented, and their possible evolution. These technological features concern the methods of flake production, the presence/absence, diversity, standardization and the intense configuration of small retouched tools on flakes; and the presence/absence of large bifacial tools (Table 4).

Table 4

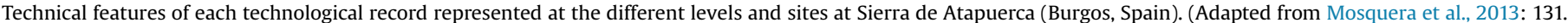
Numbers of items for each level until 2013 (Ollé et al., 2013).

\begin{tabular}{|c|c|c|c|c|c|c|}
\hline Atapuerca & & $\begin{array}{l}\text { TE9 }(\mathrm{n}=71) \\
\text { TD3-4 }(\mathrm{n}=5)\end{array}$ & $\begin{array}{l}\text { TE13-14 } \\
(\mathrm{n}=9)\end{array}$ & $\begin{array}{l}\text { TD6 } \\
(\mathrm{n}=1000)\end{array}$ & $\begin{array}{l}\text { TG-SH-TD10 } \\
(\mathrm{n}>32,500)\end{array}$ & $\begin{array}{l}\text { Upper TD10.1 } \\
(\mathrm{n}=464)\end{array}$ \\
\hline \multirow[t]{4}{*}{ Knapping model } & $\begin{array}{l}\text { Existence of one simple production method, often } \\
\text { Unipolar longitudinal }\end{array}$ & Yes & & & & \\
\hline & $\begin{array}{l}\text { Diversification of production methods: Centripetal, } \\
\text { Unipolar, Orthogonal, Multidirectional, Bipolar }\end{array}$ & & & Yes & & \\
\hline & $\begin{array}{l}\text { Diversification of production methods, but } \\
\text { dominance of Centripetal. }\end{array}$ & & & & Yes & \\
\hline & $\begin{array}{l}\text { Centripetal method }+ \text { development of preferential } \\
\text { flakes' methods (Levallois) }\end{array}$ & & & & & Yes \\
\hline \multirow{3}{*}{$\begin{array}{l}\text { Small retouched } \\
\text { tools }\end{array}$} & Small retouched flakes & No & Few & Yes & Yes & Yes \\
\hline & $\begin{array}{l}\text { Small tools diversity, standardization, continuity } \\
\text { of retouch, intense configuration }\end{array}$ & No & & No & Yes & Yes \\
\hline & Presence of (side)scrapers? & No & No & Some trend & Yes & Yes \\
\hline \multirow[t]{4}{*}{ Large tools } & Choppers, chopping tools & Yes & & Yes & Yes & Yes \\
\hline & Handaxes, cleavers, picks, etc. & No & & No & Yes & Yes \\
\hline & European Mode & Early Mode 1 & Late Mode $1 ?$ & Late Mode 1 & Full \& Late Acheulean & Transit. to Mode 3 \\
\hline & Hominins & Homo sp. & & H. antecessor & H. sp. Neanderthal lineage & \\
\hline
\end{tabular}

to our consideration (Carbonell et al., 1999, 2001) and dated at c. 900 ka (Parès et al., 1995, 2013; Falguères et al., 1999; Berger et al., 2008; Arnold et al., 2014)-, and the first Middle Pleistocene levels with lithic assemblages (TD9-TD10) ascribed to the Acheulean (Ollé et al., 2013), and dated to > 400 ka (Falguères et al., 1999, 2013; Berger et al. 2008). The lower levels of the nearby site of Galería (50 m south of Gran Dolina) have a similar chronology with an Acheulean assemblage (Mosquera, 1998; Carbonell et al. 2001; García-Medrano et al. 2014) of around 400 ka (Berger et al. 2008; Falguères et al. 2013; Demuro et al. 2014). This implies that there is a lack of archaeological information in Atapuerca from between c. $900 \mathrm{ka}$ and c. $450 \mathrm{ka}$ (Mosquera et al., 2013; Ollé et al., 2013), so again there is a gap where there hypothetically may have been a technological transition between Mode 1 and the Acheulean.

In sum, only three complexes of sites in Europe have stratigraphic sequences covering part of the Early and the Middle
Examining the scientific literature for these parameters in other European assemblages leads to several conclusions. Firstly, most of the European Mode 1- Early Pleistocene assemblages display a single technique for flake production, usually the unipolar longitudinal (e.g. Atapuerca-TE9 (De Lombera-Hermida et al., 2015), Lézignan-la-Cèbe (Crochet et al., 2009), Pont de Lavaud (Despriée et al., 2006), Atapuerca-TD3-4 (Ollé et al.,2013), Vallparadís (Martínez et al., 2010), Happisburgh (Parfitt et al., 2010) and Pakefield (Parfitt et al., 2005). However, the orthogonal, bipolar on anvil and even centripetal methods (Fuente Nueva and Barranco León (Toro-Moyano et al., 2013; Barsky et al., 2014), Pirro Nord (Arzarello et al., 2007; Arzarello and Peretto, 2010), Monte Poggiolo (Peretto et al., 1998; Arzarello and Peretto, 2010), and AtapuercaTD6 (Carbonell et al., 1999) may be represented as well. Centripetal dominance developed and became generalized from the first half of the Middle Pleistocene onwards, with level P of La Caune de l'Arago the oldest example recorded in Europe (Barsky, 2013). Later, 
in the second half of the Middle Pleistocene the Levallois and other prepared core techniques developed (Atapuerca-Upper TD10.1 (Ollé et al., 2013), La Caune de l'Arago G (Barsky, 2013), Orgnac 3 (Moncel et al., 2005), and others).

Secondly, and according to the scientific literature, small retouched flakes are absent or very rare in the earliest European assemblages ( $\geq 1 \mathrm{Ma}$ ) (Barranco León, and perhaps Le Vallonnet with one possible item). Sites such as Lézignan-la-Cèbe, Pirro Nord, Fuente Nueva 3, Atapuerca-TE9, Pont-de-Lavaud, and AtapuercaTD3-4 have not yielded any of these types of tools. They tend to appear in European sites at the Matuyama/Brunhes transition (Vallparadís, Happisburgh and Atapuerca-TD6), but they lack diversity and intense configuration. They are mainly notches and denticulates, but sometimes there are a few pointed forms such as becs in sites such as Vallparadís and Atapuerca-TD6, similar to those recorded at Barranc de la Boella. Further, the assemblage of Atapuerca-TD6 maybe one of the only assemblages in Europe in which there is an increased presence of small tools on flakes (c. 6\%), which exhibit a higher degree of diversity and standardization. Together with denticulates and notches, abrupts and sidescrapers start to appear. This last morphotype will develop in Europe from the second half of the Middle Pleistocene onwards. A review of the literature also indicates that the presence of choppers and chopping tools is independent of the assemblage being Mode 1 or Acheulean, although in Europe the numbers of these tools tend to increase in Acheulean assemblages.

Additionally, large flake production, which is one of the significant thresholds of the Acheulean, has not been documented at any European Early Pleistocene site. In the case of Atapuerca-TD6, there are only two flakes measuring more than $10 \mathrm{~cm}$ (the standard minimum measurement for a flake to be considered large), one of which is slightly retouched, among a set of 735 pieces whose state of conservation was high enough to undergo analysis. However, the large cutting tools from the Middle Pleistocene Acheulean at the cave of Galería (Atapuerca), for example, are made both on large flakes and cobbles (García-Medrano et al. 2014), which means that the production of large flakes is common in the southern Acheulean, but not a necessary factor for the production of handaxes and cleavers using this technology. Actually, LCT on cobble are more common in the lower levels of Galería, while the upper levels yield more LCT on flake. Given that the landscape was the same and that the availability of raw materials did not changed during the Galería sequence, this fact may point to a certain degree of technological evolution of the Acheulean in Europe. Similar evidences come from the early Middle Pleistocene Acheulean assemblage of La Noira (France), dated in $700 \mathrm{ka}$, where large flake production, together with LCT on slabs, is already present (Moncel et al. 2013).

It is therefore clear that tools like handaxes, cleavers and picks are not present in late Early Pleistocene assemblages in Europe. When they appear for the first time as one pick and one cleaver-like tool at Barranc de la Boella c. $900 \mathrm{ka}$, they are accompanied by a simple production method, often unipolar longitudinal, or by the limited diversification seen at other European late Early Pleistocene sites, but not by the dominance of the centripetal method, which is typical of the later Acheulean assemblages. Barranc de la Boella also yielded small tools on flakes, but mostly notches and denticulates, with very little diversity, as well as two of the becked tools, in addition to choppers and chopper-cores.

Based on these results, almost any of the late Mode 1 European assemblages may technologically resemble that of Barranc de la Boella, although one of the richest and technically closest would be Atapuerca-TD6. Then, the question is to explain which among the technical features represented at Atapuerca-TD6 could have been the possible predecessors to these documented in the Barranc de la
Boella Acheulean record. In our view, TD6 contains some of the outstanding features characteristics of the Acheulean: diversification and higher numbers of small tools on flakes, regarding Mode 1 records; certain degree of raw material differential use; and two examples of what may be large flakes. On the contrary, TD6 lacks large tools at all, and the diversification in knapping methods (although a centripetal method is sparsely present) seems to point to an evolved Mode 1, instead of a developed Acheulean, in which the centripetal knapping technique generalized and became dominant.

Also, if the Acheulean record from Barranc de la Boella may come from an evolution of the evolved Mode 1 of Atapuerca-TD6, where could the tool morphologies such as the pick and the cleaver-like tool at Barranc de la Boella have evolved from? Did they evolve from choppers and chopping tools? In Europe, we arrive at the same point as in Africa: an abrupt discontinuity.

Early forms of large cutting tools may have been invented several times throughout prehistory in distant geographic areas, following a process of convergence (Boeda, 2014). In this case, it would be useless to search for transitional morphologies and assemblages, and the discovery of similar tools at Ubeidiya, East Africa and, for example, Barranc de la Boella, would be attributable to the fact that they were invented more than once. Maybe these early picks and cleavers were per se the "technical transition" that we are searching for. In this case, the European Early Acheulean represented by Barranc de la Boella would actually be the transition to what we know as the Acheulean, the developed Acheulean typical of the European Middle Pleistocene.

If so, there is no need to conjecture population arrivals or cultural diffusion, but there is a need to explain how it is possible that a technological invention of this magnitude - retained even up to now - could have occurred just at a time when the demographic environment of the European subcontinent seems to have been so poor.

Alternatively, these morphologies may have come from elsewhere, either through peopling or cultural diffusion, but again the latter seems unlikely in a subcontinent as uninhabited as Europe was during the Matuyama/Brunhes transition. The arrival of populations or human groups may be a possibility, especially taking into account that Barranc de la Boella is in the Mediterranean area. Both in the case of convergence and peopling, the conclusion must be drawn that this technological innovation was unsuccessful in demographic terms until the arrival of the developed Acheulean in Europe approximately $500 \mathrm{ka}$.

\section{Conclusions}

According to the scientific literature, the origin of the African Acheulean seems to have been rather abrupt. The same happens in Europe, where none of the sites contains any levels with a visible transition between Mode 1 and the Acheulean. Either they show technological gaps between continuous fossiliferous deposits or the assemblages are simply at different sites. At any rate, there is an archaeological gap in Europe between the Matuyama/Brunhes transition and around $600 \mathrm{ka}$, which may point to a depopulation of the subcontinent (Mosquera et al., 2013).

At Barranc de la Boella, the three localities (El Forn, La Mina and Pit 1) are peri-contemporary, and the lack of large cutting tools at La Mina may be result of chance, in the same way that Pit 1 , which contains the finest flakes and the well shaped schist pick, is the only assemblage that lacks chopper-cores, and also breaks the pattern followed at other localities concerning the exclusive selection of chert for core products.

Therefore, the presence of large tools on "flakes", particularly in the low numbers gathered at the excavated localities, may be the 
result of chance, just as the other features that differentiate the three localities may be the result of particular occupational circumstances. However, at least the Pit 1 and El Forn assemblages can be ascribed to the European Early Acheulean, because of both the chronology and the technological features of the pick and the cleaver-like tool: in both cases the support is half of an unprepared cobble with a very marked bulb - technically making it a flake but it is so massive that it is not possible to distinguish it from a split cobble.

Only a few of the assemblages considered as Mode 1 (e.g. Atapuerca-TD6, Barranco León) may be closer to Barranc de la Boella, given the standardization of knapping methods, the presence of retouched flakes and the presence of chopper-cores, choppers and chopping-tools. Certainly, nothing in these Mode 1 records points to the evolution from choppers and chopping tools, or even from pointed denticulates and becs (Atapuerca-TD6 and Vallparadís), towards picks and cleavers. However, this might be the case of the Barranc de la Boella Acheulean: an invention, a step forward from local technologies that tends to occur whenever a community reaches a high level of technological-cognitive skills. Alternatively, the Barranc de la Boella Acheulean may have come from the Near East or Africa, given its Mediterranean location and the scarcity of sites (demography) at that time to ensure cultural contact and local evolution.

Unfortunately, the other levels in each locality of the Barranc de la Boella do not provide information with regard to any of these hypothesis, because their records are made up of very few items, and also because, interestingly, they exhibit similar features to the main level (level 2 at all the sites). For example, levels 1 and 3 of La Mina yielded percussion material and chopper-cores, as did level 2; levels 1 and 4 of El Forn yielded chert cores knapped by means of bipolar opposed and centripetal-like methods, as did level 2 and 3; levels 1 and 3 of Pit1 yielded percussion material, and notches and denticulates, as did level 2 - the butchering site. Therefore, nothing points to a change in technology at each locality.

To date, insufficient evidence has been collected to ascertain whether this European Early Acheulean was imported or evolved from local (regional) background. Anyway, it does not seem to have had continuity - particularly in demographic terms - as, actually, did no other technology in Europe, based on the archaeological gap that seems to have occurred between 900 and $600 \mathrm{ka}$ across the subcontinent. We hope that further excavations and research at Barranc de la Boella will help us to better understand this and other questions.

\section{Acknowledgments}

The authors are grateful to all of the participants in the fieldwork at Barranc de la Boella sites. Research at Barranc de la Boella has been carried out with the financial support of the Spanish Ministerio de Economía y Competitividad projects: CGL201238434-C03-03; CGL2012-38358; HAR2012-32548. Generalitat de Catalunya, AGAUR agence, provided projects 2014 SGR 899: 2014 SGR 901. A. Pineda is beneficiary of a predoctoral research fellowship (FI) from AGAUR (FI-DGR 2015). Financial support for Barranc de la Boella field work and archaeological excavations is provided by the Ajuntament de la Canonja and Departament de Cultura (Servei d'Arqueologia i Paleontologia) de la Generalitat de Catalunya (DGABMP). We are grateful to Oriol Cortes and the Boella staff in order to facilitate field assistance on the Barranc de la Boella localities. The authors wish to thank the suggestions of the reviewers for their valuable comments on the African debate, and the Guest Editor, Deborah Barsky, for the English revision of the final manuscript.

\section{References}

Arnold, L.J., Demuro, M., Parés, J.M., Pérez-González, A., Arsuaga, J.L., Bermúdez de Castro, J.M., Carbonell, E., 2014. Evaluating the suitability of extended-range luminescence dating techniques over early and Middle Pleistocene timescales: published datasets and case studies from Atapuerca, Spain. Quaternary International. http://dx.doi.org/10.1016/j.quaint.2014.08.010.

Arzarello, M., Marcolini, F., Pavia, G., Pavia, M., Petronio, C., Petrucci, M., Rook, L. Sardella, R., 2007. Evidence of earliest human occurrence in Europe: the site of Pirro Nord (Southern Italy). Naturwissenschaften 94, 107-112.

Arzarello, M., Peretto, C., 2010. Out of Africa: the first evidence of Italian peninsula occupation. Quaternary International 223-224, 65-70.

Bar-Yosef, O., Goren-Inbar, N., 1993. The Lithic Assemblage of Ubeidiya. A Lower Palaeolithic Site in the Jordan Valley. Institute of Archaeology, Hebrew University of Jerusalem, Jerusalem.

Bar-Yosef, O., Belfer-Cohen, A., 2001. From Africa to Eurasia: early dispersals. Quaternary International $75,19-28$.

Barsky, D., 2013. The Caune de l'Arago stone industries in their stratigraphical context. Comptes Rendus Palevol 12 (5), 305-325.

Barsky, D., Sala, R., Menéndez, L., Toro-Moyano, I., 2014. Use and re-use: re-knapped flakes from the Mode 1 site of Fuente Nueva 3 (Orce, Andalucía, Spain). Quaternary International. http://dx.doi.org/10.1016/j.quaint.2014.01.048.

Berger, G.W., Pérez-González, A., Carbonell, E., Arsuaga, J.L., Bermúdez de Castro, J.M., Ku, T.-L., 2008. Luminiscence chronology of cave sediments at the Atapuerca paleoanthropological site, Spain. Journal of Human Evolution 55, 300-311.

Bermúdez de Castro, J.M., Carbonell, E., Arsuaga, J.L. (Eds.), 1999. Special Issue. The Gran Dolina Site: TD6 Aurora Stratum (Atapuerca, Burgos, Spain), p. 700. Journal of Human Evolution, London.

Bermúdez de Castro, J.M., Martinón-Torres, M., Gómez-Robles, A., Prado-Simón, L. Martín-Francés, L., Lapresa, M., Olejniczak, A., Carbonell, E., 2011. Early Pleistocene human mandible from Sima del Elefante (TE) cave site in Sierra de Atapuerca (Spain): a comparative morphological study. Journal of Human Evolution 61 (1), 12-25.

Beyene, Y., Katoh, S., WoldeGabriel, G., Hart, W.K., Uto, K., Sudo, M., Kondo, M., Hyodo, M., Renne, P., Suwa, G., Asfaw, B., 2013. The characteristics and chronology of the earliest Acheulean at Konso, Ethiopia. Procedings of the Natural Academy of Sciences 110 (5), 1584-1591.

Boeda, E., 2014. Le sophisme de l'Acheuléen. In: Conference at the International Congress European Acheuleans, Organized by M-H. Moncel and D. Schreve. Museum National d'Histoire Naturelle, Paris, France, 19-21 Novembre 2014.

Bosinski, G., 1996. Les origines de l'homme en Europe et en Asie. Ed. Errance, Paris, 176 pp.

Bosinski, G., 2006. Les premiers peuplements de l'Europe centrale et de l'Est. Comptes Rendus Palevol 5, 311-317.

Carbonell, E., García-Antón, M.D., Mallol, C., Mosquera, M., Ollé, A., Rodríguez, X.P., Sahnouni, M., Sala, R., Vergès, J.M., 1999. The TD6 level lithic industry from Gran Dolina, Atapuerca (Burgos, Spain): production and use. Journal of Human Evolution 37, 653-693.

Carbonell, E., Mosquera, M., Ollé, A., Rodríguez, X.P., Sahnouni, M., Sala, R. Vergès, J.M., 2001. Structure morphotechnique de l'industrie lithique du Pléistocène infèrieur et moyen d'Atapuerca (Burgos, Espagne). L'Anthropologie 105 (2), 259-281.

Carbonell, E., Bermúdez de Castro, J.M., Arsuaga, J.L., Allué, E., Bastir M. Benito, A. Cáceres, I., Canals, A., Díez, C., Van der Made, J., Mosquera, M., Ollé, A., PérezGonzález, A., Rodríguez-López, J., Rodríguez, X.P., Rosas, A., Rosell, J., Sala, R., Vallverdú, J., Vergès, J.M., 2005. An Early Pleistocene hominin mandible from Atapuerca-TD6, Spain. Proceedings of the Natural Academy of Sciences 102 (16), 5674-5678.

Carbonell, E., Bermudez de Castro, J.M., Pares, J.M., Perez-Gonzalez, A., CuencaBescos, G. Olle, A. Mosquera, M., Huguet, R. Van der Made, J., Rosas, A., Sala, R., Vallverdú, J., Garcia, N., Granger, D.E., Martinon-Torres, M., Rodriguez, X.P., Stock, G.M., Verges, J.M., Allue, E., Burjachs, F., Caceres, I., Canals, A., Benito, A., Diez, C., Lozano, M., Mateos, A., Navazo, M., Rodriguez, J., Rosell, J., Arsuaga, J.L., 2008. The first hominin of Europe. Nature 452, 465-469.

Crochet, J.-Y., Welcomme, J.-L., Ivorra, J., Ruffet, G., Boulbes, N., Capdevila, R., Claude, J., Firmat, C., Métais, G., Michaux, J., Pickford, M., 2009. Une nouvelle faune de vertébrés continentaux, associée à des artefacts dans le Pléistocène inférieur de l'Hérault (Sud de la France), vers 1,57 Ma. Comptes Rendus Palevol 8 (8), 725-736.

Despriée, J., Gageonnet, R., Voinchet, P., Bahain, J.J., Falguères, C., Varache, F., Courcimault, G., Dolo, J.-M., 2006. Une occupation humaine au Pléistocène inférieur sur la bordure nord du Massif central. Comptes Rendus Palevol 5, 821-828.

De la Torre, I., 2004. Estrategias tecnológicas en el Pleistoceno Inferior de África Oriental (Olduvai y Peninj, Norte de Tanzania). Dpto. Prehistoria. Universidad Complutense de Madrid, Madrid, p. 612.

De la Torre, I., Mora, R., 2005. Technological Strategies in the Lower Pleistocene at Olduvai Beds I and II. ERAUL, vol. 112. University of Liège Press, Liège, p. 255.

De la Torre, I., 2009. Technological Strategies in the Lower Pleistocene at Peninj (West of Lake Natron, Tanzania). In: Toth, K.S.N. (Ed.), The Cutting Edge: New Approaches to the Archaeology of Human Origins. Stone Age Institute Press, Bloomington, pp. 93-113.

De la Torre, I., Mora, R., 2013. The transition to the Acheulean in East Africa: an assessment of paradigms and evidence from Olduvai Gorge (Tanzania). Journal of Archaeological Method and Theory 21, 781-823. 
De Lombera-Hermida, A., Bargalló, A., et al., 2015. The lithic industry of Sima del Elefante (Atapuerca, Burgos, Spain) in the context of Early and Middle Pleistocene technology in Europe. Journal of Human Evolution 82 (0), 95-106.

Díez-Martín, F., Cuartero, F., Sánchez-Yustos, P., Baena, J., Domínguez-Rodrigo, M. Rubio, D., 2012. Testing cognitive skills in Early Pleistocene hominins: an analysis of the concepts of hierarchization and predetermination in the lithic assemblages of Type Section (Peninj, Tanzania). In: Domínguez-Rodrigo, M. (Ed.), Stone Tools and Fossil Bones. Current Debates in the Archaeology of Human Origins. Cambridge University Press, Cambridge, pp. 245-300.

Espigares, M.P., Martínez-Navarro, B., Palmqvist, P., Ros-Montoya, S., Toro, I., Agustí, J., Sala, R., 2013. Homo vs. Pachycrocuta: earliest evidence of competition for an elephant carcass between scavengers at Fuente Nueva-3 (Orce, Spain). Quaternary International 295, 113-125.

Falguères, C., Bahain, J.J., Yokoyama, Y., Arsuaga, J.L., Bermúdez de Castro, J.M., Carbonell, E., Bischoff, J.L., Dolo, J.-M., 1999. Earliest humans in Europe: the age of TD6 Gran Dolina, Atapuerca, Spain. Journal of Human Evolution 37, $343-352$.

Falguères, C., Bahain, J.-J., Bischoff, J.L., Pérez-González, A., Ortega, A.I., Ollé, A., Quiles, A., Ghaleb, B., Moreno, D., Dolo, J.-M., Shao, Q. Vallverdú, J., Carbonell, E. Bermúdez de Castro, J.M., Arsuaga, J.L., 2013. Combined ESR/U-series chronology of Acheulian hominid-bearing layers at Trinchera Galería site, Atapuerca, Spain. Journal of Human Evolution 65, 168-184.

Gallotti, R., 2013. An older origin for the Acheulean at Melka Kunture (Upper Awash, Ethiopia): techno-economic behaviours at Garba IVD. Journal of Human Evolution 65 (5), 594-620.

García-Medrano, P., Ollé, A., Mosquera, M., Cáceres, I., Díez, C., Carbonell, E., 2014. The earliest Acheulean technology at Atapuerca (Burgos, Spain): oldest levels of the Galería site (GII Unit). Quaternary International 353, 170-194.

Gaudzinski, S., Bittman, F., Boenigk, W., Frechen, M., Van Kolfschoten, T., 1996 Palaeoecology and Archaeology of the Kärlich-Seeufer Open-Air Site (Middle Pleistocene) in the Central Rhineland, Germany. Quaternary Research 46, 319-334.

Haidle, M.N., Pawlik, A.F., 2010. The earliest settlement of Germany: Is there anything out there? Quaternary International 223-224, 143-153.

Haynes, G., 1991. Mammoths, Mastodants and Elephants: Biology, Behavior and the Fossil Record. Cambridge University Press, Cambridge.

Isaac, G.L., 1978. The food-sharing behavior of protohuman hominids. Scientific American 238, 90-108.

Jiménez-Arenas, J.M., Santonja, M., Botella, M., Palmqvist, P., 2011. The oldest handaxes in Europe: fact or artefact? Journal of Archaeological Science 38 (12), $3340-3349$.

Kimura, Y., 2002. Examining time trends in the Oldowan technology at Beds I and II, Olduvai Gorge. Journal of Human Evolution 43, 291-321.

Koulakovska, L., Usik, V., Haesaerts, P., 2010. Early Paleolithic of Korolevo site (Transcarpathia, Ukraine). Quaternary International 223-224, 116-130.

Leakey, M.D., 1971. Olduvai Gorge. Excavations in Beds I and II, 1960-1963, vol. 3. Cambridge University Press, London.

Lepre, C.J., Roche, H., Kent, D.V., Harmand, S., Quinn, R.L., Brugal, J.-P., Texier, P.-J., Lenoble, A., Feibel, C.S., 2011. An earlier origin for the Acheulian. Nature 477, 82-85.

Lozano-Fernández, I., Agustí, J., Cuenca, G., Blain, H., López-García, J.M., Vallverdú, J., 2013. Pleistocene evolutionary trends in dental morphology of Mimomys savini (Rodentia, mammalia) from Iberian Peninsula and discussion about the origin of the genus Arvicola. Quaternaire 24 (2), 179-190.

Lozano-Fernández, I., Bañuls-Cardona, S., Blain, H.-A., López-García, J.M., Vallverdú, J., Agustí, J., Cuenca-Bescós, G., 2014. Biochronological data inferred from the Early Pleistocene small mammals of the Barranc de la Boella site (Tarragona, north-eastern Spain). Journal of Quaternary Science 29 (7), $722-728$.

Martínez, K., García, J., Carbonell, E., Agustí, J., Bahain, J.J., Blain, H.A., Burjachs, F., Cáceres, I., Duval, M., Falgueres, C., Gómez, M., Huguet, R., 2010. A new Lower Pleistocene archeological site in Europe (Vallparadís, Barcelona, Spain). Proceedings of the National Academy of Sciences 107 (13), 5762-5767.

Moncel, M.-H., Moigne, A.-M., Combier, J., 2005. Pre-Neandertal behaviour during isotopic stage 9 and the beginning of stage 8 . New data concerning fauna and lithics in the different occupation levels of Orgnac 3 (Ardèche, South-East France): occupation types. Journal of Archaeological Science 32, 1283-1301.

Moncel, M.-H., Desprié, J., Voinchet, P. Tissoux, H., Moreno, D., Bahain, J.-J. Courcimault, G., Falguères, C., 2013. Early evidence of Acheulean settlement in northwestern Europe - la Noira site, a 700000 year-old occupation in the center of France. PLoS One 8 (11), e75529.

Mora, R., De la Torre, I., 2005. Percussion tools in Olduvai Beds I and II (Tanzania): implications for early human activities. Journal of Anthropological Archaeology 24, 179-192.

Mosquera, M., 1998. Differential raw material use in the Middle Pleistocene of Spain: evidence from Sierra de Atapuerca, Torralba, Ambrona and Aridos. Cambridge Archaeological Journal 8, 15-28.

Mosquera, M., Ollé, A., Rodríguez, X.P., 2013. From Atapuerca to Europe: tracing the earliest peopling of Europe. Quaternary International 295, 130-137.

Mosquera, M., Saladié, P., Ollé, A., Cáceres, I., Huguet, R., Estéban, M., Menéndez, L., Vilalta, J., Benàssar, L., Expósito, I., Ros, S., Vergès, J.M., Villalaín, J.J., Carrancho, A., Martínez-Navarro, B., Agustí, J., Vallverdú, J., Barranc de la Boella (Catalonia, Spain): an Acheulean elephant butchery site at the European late Early Pleistocene. Journal of Quaternary Science (accepted).
Ollé, A., Mosquera, M., Rodríguez, X.P., de Lombera-Hermida, A., García-Antón, M.D. García-Medrano, P., Peña, L., Menéndez, L., Navazo, M., Terradillos, M., Bargalló, A., Márquez, B., Sala, R., Carbonell, E., 2013. The Early and Middle Pleistocene technological record from Sierra de Atapuerca (Burgos, Spain). Quaternary International 295, 138-167.

Parés, J.M., Arnold, L.J., Duval, M., Demuro, M., Pérez-González, A., Bermúdez de Castro, J.M., Carbonell, E., Arsuaga, J.L., 2013. Reassessing the age of AtapuercaTD6 (Spain): new paleomagnetic results. Journal of Archaeological Science 40, 4586-4595.

Parés, J.M., Pérez-González, A., 1995. Paleomagnetic age for hominid fossils at Atapuerca archaeological site, Spain. Science 269, 830-832.

Parfitt, S.A., Barendregt, R.W., Breda, M., Candy, I., Collins, M.J., Coope, G.R., Durbidge, P., Field, M.H., Lee, J.R., Lister, A.M., Mutch, R., Penkman, K.E.H., Preece, R.C., Rose, J., Stringer, C.B., Symmons, R., Whittaker, J.E., Wymer, J.J. Stuart, A.J., 2005. The earliest record of human activity in northern Europe. Nature 438, 1008-1012.

Parfitt, S.A., Ashton, N.M., Lewis, S.G., Abel, R.L., Coope, G.R., Field, M.H., Gale, R., Hoare, P.G., Larkin, N.R., Lewis, M.D., Karloukovski, V., Maher, B.A., Peglar, S.M., Preece, R.C., Whittaker, J.E., Stringer, C.B., 2010. Early Pleistocene human occupation at the edge of the boreal zone in northwest Europe. Nature 466, 229-233.

Peretto, C., Amore, F.O., Antoniazzi, A., Bahain, J.J., Cattani, L., Cavallini, E. Esposito, P., Falguères, C., Gagnepain, J., Hedley, J., Laurent, M., Lebreton, M., Longo, L., Milliken, L., Monegatti, P., Ollé, A., Pugliese, N., Ranault-Miskovski, J. Sozzi, M., Ungaro, S., Vannucci, S., Vergès, J.M., Wagner, J.J., Tokoyama, Y., 1998 L'industrie lithique de Ca'Belvedere di Monte Poggiolo: stratigraphie, matière première, typologie, remontatges et traces d'utilisation. L'Anthropologie 102 (4), 343-465.

Pineda, A., Saladié, P., Vergès, J.M., Huguet, R., Cáceres, I., Vallverdú, J., 2014 Trampling versus cut marks on chemically altered surfaces: an experimental approach and archaeological application at the Barranc de la Boella site (la Canonja, Tarragona, Spain). Journal of Archaeological Science 50, 84-93.

Rocca, R., 2013, Peut-on définir des aires culturelles au Paléolithique inférieur? Originalité des premières industries lithiques en Europe centrale dans le cadre du peuplement de l'Europe. Ecole Doctorale 395. Milieux, Cultures et Sociétés du Passé et du Présent. Université de Paris Ouest Nanterre La Défense, Nanterre, Paris, p. 562. Ph.D.

Roche, H., Brugal, J.-P., Delagnes, A., Feibel, C.S., Harmand, S., Kibunjia, M., Prat, S., Texier, J.-P., 2003. Les sites archéologiques plio-pléistocènes de la formation de Nachukui, Ouest-Turkana, Kenya : bilan synthétique 1997-2001. C. R. Palevol. 2 pp. 663-673.

Roche, H., Blumenschine, R.J., Shea, J.J., 2009. Origins and adaptations of Early Homo: what archeology tells us. In: Grine, F.E., Fleagle, J.G., Leakey, R.E. (Eds.) The First Humans - Origin and Early Evolution of the Genus Homo. Springer, New York, pp. 135-150.

Rodríguez, J., Burjachs, F., Cuenca-Bescós, G., García, N., Van der Made, J., Pérez González, A. Blain, H.A., Expósito, I., López-García, J.M., García Antón, M. Allué, E., Cáceres, I., Huguet, R., Mosquera, M., Ollé, A., Rosell, J., Parés, J.M., Rodríguez, X.P., Díez, C., Rofes, J., Sala, R., Saladié, P., Vallverdú, J., Bennasar, M.L. Blasco, R., Bermúdez de Castro, J.M., Carbonell, E., 2011. One million years of cultural evolution in a stable environment at Atapuerca (Burgos, Spain). Quaternary Science Reviews 30, 1396-1412.

Rosas, A., Pérez-González, A., Carbonell, E., Van Der Mande, J., Sánchez, A. Laplana, C., Cuenca-Bescós, G., Parés, J.M., Huguet, R., 2001. Le gisement pléistocene de la "Sima del Elefante" (Sierra de Atapuerca, Espagne). L'Anthropologie 105, 301-312.

Rosas, A., Huguet, R., Pérez-González, A., Carbonell, E., Bermúdez de Castro, J.M. Vallverdú, J., van der Made, J., Allué, E., García, N., Martínez-Pérez, R. Rodríguez, J., Sala, R., Saladie, P., Benito, A., Martínez-Maza, C., Bastir, M. Sánchez, A., Parés, J.M., 2006. The "Sima del Elefante" cave site at Atapuerca (Spain). Estudios Geológicos 62, 327-348.

Semaw, S., Rogers, M., Stout, D., 2009. The Oldowan-Acheulian Transition: is there a "Developed Oldowan”artifact tradition? In: Camps, M., Chauhan, P.R. (Eds.), Source of Paleolithic Transitions. Springer, New York, pp. 173-193.

Scott, G., Gibert, L., 2009. The oldest hand-axes in Europe. Nature 461, 82-85.

Stout, D., Chaminade, T., 2007. The evolutionary neuroscience of tool making. Neuropsychologia 45 (5), 1091-1100.

Stout, D., Toth, N., Schick, K. Chaminade, T, 2008. Neural correlates of Early Stone Age toolmaking: technology, language and cognition in human evolution. Philosophical Transactions of the Royal Society B: Biological Sciences 363 (1499), 1939-1949.

Texier, P.--., Roche, H., Harmand, S., 2006. Kokiselei 5, Formation de Nachukui, West Turkana (Kenya): un témoignage de la variablité ou de l'évolution des comportements techniques au Pléistocène Ancien? British Archaeological Reports International Series 1522, 11-22.

Toro-Moyano, I., Martínez-Navarro, B., Agustí, J., Souday, C., Bermúdez de Castro, J.M., Martinón-Torres, M., Fajardo, B., Duval, M., García-Aguilar, J.M. Moigne, A.-M., Espigares, M.P., Ros Montoya, S., Palmqvist, P., 2013. The oldest human fossil in Europe dated to ca. 1.4 Ma at Orce (Spain). Journal of Human Evolution 65 (1), 1-9.

Vallverdú, J., Saladié, P., Rosas, A., Huguet, R., Cáceres, I., Mosquera, M., GarciaTabernero, A. Estalrrich, A. Lozano-Fernández, I., Pineda-Alcalá, A. Carrancho, Á., Villalaín, J.J., Bourlés, D., Braucher, R., Lebatard, A., Vilalta, J. Esteban-Nadal, M., Bennàsar, M.L., Bastir, M., López-Polín, L., Ollé, A., 
Vergès, J.M., Ros-Montoya, S., Martínez-Navarro, B., García, A., Martinell, J. Expósito, I., Burjachs, F., Agustí, J., Carbonell, E., 2014a. Age and Date for Early Arrival of the Acheulian in Europe (Barranc de la Boella, la Canonja, Spain). PLoS ONE 9 (7), e103634.

Vallverdú, J., Saladié, P., Rosas, A., Huguet, R., Cáceres, I., Pineda, A., Ollé, A. Mosquera, M., García-Tabernero, A., Estalrich, A., Carrancho, A., Villalaín, J.J.,
Bourlès, D., Braucher, R., Lebatard, A., Vilalta, J., Lozano, I., López-Polín, L., Moreno, E., Vergès, J.M., Expósito, I., Agustí, J., Carbonell, E., Capdevila, R., 2014b.

El Barranc de la Boella (La Canonja, Tarragona, Catalonia, Spain). In: Sala, R.

(Ed.), Pleistocene and Holocene Hunter-gatherers in Iberia and the Gibraltar Strait: the Current Archaeological Record. Universidad de Burgos, Burgos, pp. 287-295.

Please cite this article in press as: Mosquera, M., et al., The Early Acheulean technology of Barranc de la Boella (Catalonia, Spain), Quaternary International (2015), http://dx.doi.org/10.1016/j.quaint.2015.05.005 